\title{
To Share or not to Share? \\ Financial Analysts' Questioning in Conference Calls
}

\begin{abstract}
:
We study whether superior financial analysts strategically reveal information in earnings conference calls. To the extent that analysts' relative information advantages translate into desirable professional outcomes, we expect superior analysts to be mindful of safeguarding their information advantages when interacting with peers. Consistently, we find that superior analysts (i.e., analysts with a higher ex-ante relative forecast accuracy) share less information in their questions during conference calls. Hereby, analysts more likely maintain their information advantages. In additional analyses, we underscore the strategic motives of information sharing. We find that analysts ask more (less) informative questions when they are exposed to a higher information uncertainty (competition). Moreover, our analyses indicate that informative questions trigger informative answers, which are not only valuable for the respective analyst but also peer analysts and capital markets. Collectively, our results shed light on the role of analysts as information intermediaries in shaping firms' information environments.
\end{abstract}

Keywords: financial analysts' incentives; conference calls; information sharing; relative forecast accuracy.

JEL codes: G24; G29; M41.

Current version: August 2021. 


\section{INTRODUCTION}

We study strategic behavior among financial analysts during earnings conference calls. Conference calls represent a strategic information exchange between a group of analysts and the firm's management, whereby the analysts depend on management-provided information for generating accurate earnings forecasts (Bowen et al., 2002). Prior literature emphasizes the strategic information exchange between analysts and the firm's management. For instance, Mayew (2008) provides evidence that the firm's management discriminates among analysts by granting participation in conference calls for analysts with favorable stock recommendations. Haag et al. (2021) find that analysts' usage of unfavorable language in questions encourages the firm's management to provide more (accurate) information. However, during conference calls, there is also a strategic information exchange within the group of analysts, as analysts are evaluated based on their relative forecast accuracy (e.g., Hong \& Kubik, 2003; Brown et al., 2015; Emery $\& \mathrm{Li}, 2009)$, which is likely to determine the informativeness of conference calls. We examine the determinants and consequences of analysts' information sharing during conference calls. More specifically, we study to what extent superior analysts preserve their information advantages in conference calls by sharing relatively less information than their peers. Additionally, we analyze the associated capital market consequences.

We expect analysts with a higher information endowment (i.e., superior analysts) to share information selectively. In particular, analysts trade off the benefits and cost of revealing information via their questions. In the negotiation context, Minson et al. (2018) provide experimental evidence that the questioner can increase the quality of information provided by the respondent by revealing information in the question. Consequently, analysts may increase the quality of management-provided information by revealing information in their questions. However, analysts have incentives to outperform their peers (Emery \& Li, 2009; Bowers et al., 2014; Brown et al., 2015). By revealing information in their questions, they would enhance other 
analysts' information endowment as the information shared becomes a public good. This potentially reduces their information advantage. In other words, analysts can safeguard their information advantage by sharing less information and thereby preventing peers from freeriding. As superior analysts depend less strongly on management-provided information and care more about maintaining or increasing their information advantage, we expect them to be less willing to share their information advantage in questions during conference calls.

We test our predictions using 260,589 analyst speech portions from quarterly earnings conference calls of all listed U.S. firms in the time-period 2008 to 2020 . We identify analysts' information endowment by their relative forecast accuracy prior to the conference call regarding next quarter's earnings. In particular, we compare analysts in terms of absolute forecast accuracy per quarterly conference call, considering forecasts by participating as well as nonparticipating analysts. ${ }^{1}$ We measure the extent to which analysts share information in conference calls as the abnormal inverse cosine similarity (i.e., cosine modification) between the management's presentation and the corresponding analysts' questions. Cosine modification captures the degree to which analysts' questions thematically differ from management's presentation and thus, the extent to which analysts add incremental information content to the conference call (see Lee, 2016; Cicon, 2017).

We document a negative association between analysts' information sharing and their ex-post relative forecast accuracy, suggesting that analysts harm their information advantage when sharing information in their questions during conference calls. Consistently, we find that superior analysts, that is analysts with a higher ex-ante relative forecast accuracy, less likely share information in their questions. Additional analyses underscore the strategic motives of analysts' information sharing in questions. We find that analysts share more (less) information when they are exposed to a higher information uncertainty (competition).

\footnotetext{
${ }^{1}$ We cannot match all participating analysts by their name, but we use the forecasts of all analysts to infer the relative quality of the questioning analyst's information endowment.
} 
In the next step, we explore the interplay between analyst questions and management answers to shed light on the underlying mechanism behind our main findings. We show that informative questions are accompanied by informative answers, especially when the questions are negatively phrased and are less specific. However, the findings suggest that managers are reluctant to provide detailed answers to informative questions. We find that informative questions are associated with shorter answers and a lower number of answers by different executives.

Finally, we explore the consequences of analyst's and management's information sharing on the respective analyst's absolute forecast accuracy, peers' forecast accuracy, and the informativeness to capital markets. We find that superior analysts not only face costs of sharing information in their questions (i.e., in terms of their relative forecast accuracy) but also benefits in terms of their absolute forecast accuracy. However, we also find that informative questions by superior analysts, that are associated by informative management answers, have positive externalities for peer analysts, i.e., we find a reduction in overall information uncertainty in response to informative questions induced by superior analysts and the following answers. Informative answers are rewarded by capital markets, however this effect diminishes when the answers are triggered by informative questions. More specifically, we provide evidence that capital markets punish managers for providing information when their information provision is triggered by analysts asking for that information, suggesting that informative questions can be interpreted as information-seeking activities by analysts that likely address critical topics.

This study contributes to three strands of research. First, we contribute to the literature on the informativeness of conference calls. Matsumoto et al. (2011) provide evidence that the Q\&A section of conference calls is more informative than the presentation section whereas Cicon (2017) shows that the informativeness of the Q\&A section is increasing with the management discussing topics that were not addressed in the management presentation. We add to this literature by investigating the role of analysts' questions in triggering the informativeness 
of management's responses. We suggest that analysts' relative performance evaluation significantly affects the extent to which they share information in questions during conference calls. More specifically, analysts with ex-ante superior information share relatively less information in the conference call, thereby triggering management's answers to also contain less information. Consequently, our results suggest that analysts' considerations with regard to relative performance evaluation reduce the informativeness of conference calls for the capital market.

Second, we indirectly contribute to the literature on learning among analysts. For instance, Kumar et al. (2020) find that analysts learn from peer analysts with similar personal characteristics (e.g., gender, ethnicity). Following Kumar et al. (2020), analysts can learn from their own experience as well as from peers' observed actions and outcomes. Thereby, the strength of analysts' incentives affects the degree to which they substitute or complement their individual effort by learning from peers (Bloomfield \& Hales, 2009). To the best of our knowledge, we provide first evidence on how analysts may hinder their peers from learning from their actions.

Third, our results provide interesting insights to the literature on managers' strategic responses to relative performance evaluation (Feichter et al., 2020; Martin \& Timmermans, 2021; Timmermans, 2020). We provide evidence that relative performance evaluation can hinder information sharing of superior agents. This is applicable to various settings, e.g., information sharing on research conferences when two researchers work on two similar projects but also managers' information sharing in firm meetings.

The remainder of the paper proceeds as follows. In Section II, we review prior literature and develop our hypotheses. We present our sample and research design in Section III. In Section IV, we report on the main findings and robustness checks. In Section V, we present additional analyses. Section VI concludes. 


\section{PRIOR RESEARCH AND HYPOTHESES DEVELOPMENT}

\section{Financial analysts' incentives}

Analysts significantly shape firms' information environments. In their role of information intermediaries, they acquire and aggregate information to subsequently disseminate aggregated information signals - in form of earnings forecasts, stock recommendations, and a report that describes certain selected topics - to their clients and the broader financial market (Asquith et al., 2005). They acquire firm-specific (Bowen et al., 2002) and macroeconomic information (e.g., Hugon et al., 2016) from a variety of different public as well as private (Healy \& Palepu, 2001) information sources. Prior literature suggests that analysts' disseminated information signals contain incremental information content beyond the firm-specific information that is already publicly available (Asquith et al., 2005; Loh \& Stulz, 2011), underscoring the value of analysts for capital markets.

Brown et al. (2015) suggest that analysts are exposed to explicit as well as implicit incentives, i.e., they are compensated by performance-based pay and are exposed to career concerns. Among other factors like the amount of generated investment banking business or trading volume, prior literature concludes that the forecast accuracy is one of the most important determinants of analysts' compensation and reputation (Brown et al., 2015). Forecast accuracy can be measured in an absolute or relative sense. Absolute forecast accuracy compares the individual analyst's forecast with the realized earnings number, whereas the concept of relative forecast accuracy sets the individual absolute forecast accuracy in perspective to the performance of all peers that cover a certain firm (e.g., Hong \& Kubik, 2003).

Following prior research, we argue that analysts are incentivized to increase absolute forecast accuracy. For instance, Chen et al. (2005) find that investors evaluate analyst's ability based on her record of past absolute forecast accuracy. Consistently, Brown et al. (2015) provide survey-based evidence indicating that the accuracy demand of their clients is one of the top priorities of analysts. Furthermore, analysts are incentivized to generate accurate earnings 
forecasts as they represent an essential input of their valuation models to derive stock recommendations (Loh \& Mian, 2006; Brown et al., 2015). Hence, if analysts generate inaccurate earnings forecasts, their valuation model relies on inaccurate input parameters, likely resulting in unprofitable stock recommendations (Ertimur et al., 2007).

Additionally, prior literature shows that analysts also have incentives to outperform their peers, underlining analysts' preference for relative forecast accuracy. Those are primarily termination based and are not explicitly tied to the individual compensation (Groysberg et al., 2011). Mikhail et al. (1999) find that analysts with lower relative forecast accuracy are more likely to be turned over. In a similar vein, Hong and Kubik (2003) show that higher relative forecast accuracy leads to a higher likelihood to experience career advancements like a transition to a brokerage house that maintains a top-tier status. Furthermore, relative performance is also an important determinant of whether an analyst is considered as a star analyst by established rankings (e.g., Institutional Investors - All American Research Team) (Stickel, 1992; Emery \& Li, 2009), whereby a higher rank in those ratings is typically associated with an increase in compensation and career advancements (e.g., Groysberg et al., 2011). ${ }^{2}$ Overall, these findings of prior literature are grounded on the theoretical notion that the evaluation in a competitive situation is based on relative performance (Milgrom \& Roberts, 1992).

\section{Information provision during earnings conference calls}

Conference calls represent an important information source for analysts (Bowen et al., 2002; Brown et al., 2015). While analysts have good knowledge on industry related factors affecting firm-performance, managers are better informed than analysts on firm-specific factors affecting

\footnotetext{
${ }^{2}$ We do not consider all-star ratings in our empirical analysis as they are partly survey-based, therefore contain individual judgements about the analyst, and thus 'only' represent a subjective type of relative performance evaluation. This implies that the dichotomous all-star listing only provides a very limited indication about the heterogenous quality of each respective analyst's underlying information. Additionally, we do not consider all-star ratings as we are interested in short-term information advantages, whereas ratings capture analyst's ability, which is rather long-term, as well as analysts' reputation.
} 
firm-performance (Hutton et al., 2012). Hutton et al. (2012) document that management forecasts are more accurate compared to analyst forecasts when analysts face difficulties in anticipating managerial actions that ultimately affect earnings. More specifically, Hutton et al. (2012) find that managers outperform analysts in forecasting when the firm has abnormally high inventories, excess capacity, or experiences a loss. Consequently, analysts have incentives to acquire or at least validate their information during conference calls to increase their absolute forecast accuracy. In particular, by sharing information in their questions managers more likely provide more (less biased) information (in line with Minson et al., 2018; Haag et al., 2021). ${ }^{3}$

Conference calls are organized as a two-staged disclosure process. In the first part, the management gives a brief, scripted presentation that includes the managements' notion of the firms' past and future performance ${ }^{4}$, whereas in the second part, the question and answer section, participants, mainly analysts, have the opportunity to directly address a question to the management (Matsumoto et al., 2011). Against the backdrop of Regulation Fair Disclosure $(\operatorname{Reg} F D)$, this is the only opportunity to directly approach the management for material information. Matsumoto et al. (2011) provide evidence that the Q\&A section is more informative than the management presentation. They argue that their findings can be explained by the spontaneous character of the Q\&A session driven by the active involvement of analysts. This is in line with (later) evidence showing that the incremental informativeness of the Q\&A section over the management presentation stems from answers that discuss topics that were not covered in the presentation section (Cicon, 2017) as well as the fact that the management prepares only a limited number of answer scripts, i.e., has to spontaneously answer certain analysts' questions (Lee, 2016).

\footnotetext{
${ }^{3}$ Additionally, analysts could also be inclined to ask informative questions in order to signal knowledge to investors and other listeners to the conference call.

${ }^{4}$ Prior literature commonly refers to the management presentation as prepared remarks (Lee 2016). In this section, the management addresses various forward- as well as backward-looking financial or nonfinancial topics (Matsumoto et al. 2011). For example, Timothy Cook's and Luca Maestri's presentation in Apple's Q3 2019 conference call comprised detailed backward-looking segment information, details on the acquisition of Intel's smartphone modem business, information on future software and product releases, etc.
} 
In general, analysts face the decision whether to participate in conference calls or not. By actively participating, analysts can improve their information endowment with regard to firm performance (in line with Minson et al., 2018; Haag et al., 2021), demonstrate visibility and build personal reputation with clients, management, and other listeners (Abraham \& Bamber, 2017), and listen to the questions of other analysts (Christensen and Associates, 1992). ${ }^{5}$ With a certain question, analysts can ask about specific information they are currently lacking in their forecasting model and thereby improve their forecasts. Moreover, clients, who also listen to the conference call, may view the respective analyst as more credible if she gains the opportunity to publicly discuss certain topics with the senior management of the firm. A consequence may be an improved number of client votes, which is a major determinant of analysts' compensation (Brown et al., 2015). Reputation building with the management increases the likelihood of getting access to future conference calls as well as facilitates exclusive access to the management after the conference call (Mayew, 2008). Based on the results of prior literature and anecdotal evidence from interviews with analysts, we assume that non-participation is not beneficial due to reputation and credibility costs.

Analysts participating in the call can influence the information content of the conference call by the way they phrase their question as well as its content. Haag et al. (2021) find that phrasing questions unfavorably encourages the firm's management to provide more (accurate) information, suggesting that unfavorable language increases the quality of management-provided information during the conference call. This finding is consistent with evidence from the negotiation context indicating that the questioner can increase the quality of information provided in the response by asking negative assumption questions, which signal knowledgeability (i.e., high quality information) and assertiveness (Minson et al., 2018). Furthermore, Call et al.

\footnotetext{
${ }^{5}$ Other listeners including, among others, headhunters, competing brokerage houses, and investment banks may determine whether they offer an employment contract to an analyst based on its access to the management (Abraham \& Bamber, 2017).
} 
(2020) show that analysts' use of humor leads to longer answers and an increased likelihood to ask follow-up questions. Related to the content of the question, if analysts ask questions referring to critical topics, the managements' likelihood to not answer this question is higher, publicly indicating managements' unwillingness to disclose information on this topic (Gow et al., 2021).

\section{Hypotheses development}

Against this backdrop, we study the consequences of analysts' information sharing during conference calls in terms of their relative forecast accuracy. Moreover, we examine whether analysts' ex-ante information endowment explains their information sharing behavior.

We argue that each analyst possesses some kind of private information before the conference call due to her individual information collection and interpretation activities and abilities (Huang et al., 2018). In particular, analysts generate information advantages as they may have access to proprietary macroeconomic data and the skills and time to analyze the data. Moreover, analysts typically cover many firms in the same industry providing them knowledge on key competitors and industry dynamics. Finally, analysts may differ in their ability to put together all information pieces needed to assess the influence of macroeconomic and industry determinants on corporate performance (in line with Hutton et al., 2012).

We study the cost associated with information sharing: Sharing information in questions may be costly to analysts in terms of their relative forecast accuracy. When an analyst reveals her private information advantage in her questions (which arguably induces an informative management answer), she likely provides peer analysts with a 'new' piece of information that enables them to increase their forecast accuracy and, in turn, diminishes the focal analyst's relative information advantage ex-post. The argument is consistent with Kumar et al. (2020) suggesting that analysts can learn from peers' observed actions. Moreover, it is consistent with anecdotal evidence from an expert interview with an analyst who indicates that analysts diligently consider the questions of their peers. Since analysts typically issue earnings forecasts 
under time pressure, freeriding on peers' information endowment reduces information acquisition and interpretation costs while at the same time ensuring accurate forecasts (in line with Verrecchia, 1982; Diamond, 1985). This does not only hold for the group of analysts participating in the conference call, who can freely listen to others' questions, but also for non-participating analysts, who can ex-post read the accompanied conference call transcript. Thus, we expect analysts to experience a decrease in relative forecast accuracy when they share information in their questions, e.g., by asking questions unrelated to the topics discussed in the presentation section. We summarize our prediction in Hypothesis H1:

H1: Information sharing in questions during earnings conference calls is negatively associated with financial analysts' relative forecast accuracy.

Hypothesis $\mathrm{H} 2$ deals with the question of how analysts' ex-ante information endowment affects their information sharing behavior during conference calls. We predict superior analysts, i.e., analysts with a higher relative forecast accuracy, to share less information. A higher relative forecast accuracy may originate from higher firm experience or better resources due the size of the brokerage house.

In particular, we expect superior analysts to more strongly care about their relative forecast accuracy than their absolute forecast accuracy as they are already characterized by high absolute forecast accuracy ex-ante and are strongly incentivized to issue relatively accurate forecasts. Since sharing information is arguably associated with a decrease in relative forecast accuracy (i.e., peer analysts can freeride on analysts' provided information in their questions and the subsequent management answers, see Hypothesis H1), analysts' marginal benefits from information sharing decrease with their ex-ante information endowment. Thus, we expect superior analysts to share less information in their questions to avoid that their private information is becoming a public good. We summarize our expectation in Hypothesis $\mathrm{H} 2$ :

H2: Superior financial analysts share less information in their questions during earnings conference calls. 


\section{SAMPLE AND RESEARCH DESIGN}

\section{Data sources and sample}

Our sample contains the quarterly earnings conference call transcripts ${ }^{6}$ of all US-listed companies held in the time-period between January 2008 and September 2020 downloaded from Thomson Reuters EIKON. We obtained quarterly firm fundamentals from Compustat and the individual analyst data from I/B/E/S detail and recommendation files. In line with prior literature, we apply a fuzzy-name matching approach to match each respective analyst speech portions to the I/B/E/S detail file using the I/B/E/S recommendation file (Mayew et al., 2020; Call et al., 2020) ${ }^{7}$, which contains the full name of analysts who did not initiate an anonymization (e.g., Ljungqvist et al., 2009) ${ }^{8}$. The sample selection process is summarized in Table 1.

[Please insert Table 1 here]

As we perform analyses on the individual analyst- as well as the firm-level, our final sample contains observations on both levels. Our analyst-level sample contains 260,589 analyst speech portions ${ }^{9}$ from 3,288 different analysts. On the firm-level, our sample consists of 70,089 transcripts, suggesting that we were able to match on average 3.72 speech portions per conference call.

\section{Measurement of information sharing in analysts' questions}

Our measurement of information sharing is motivated by Lee (2016) and Cicon (2017), who investigate the incremental informativeness of the Q\&A session. Lee (2016) provides evidence that managers' adherence to predetermined scripts is associated with higher bid-ask spreads and negative stock market reactions, suggesting that scripted answers increase the uncertainty in the

\footnotetext{
${ }^{6}$ Our sample only contains conference call transcripts that are held in conjunction with an earnings announcement. Hence, we do not consider any extraordinary conference calls that are held due to e.g., a merger or an acquisition. ${ }^{7}$ Using a fuzzy-name matching approach implies that $\mathrm{I} / \mathrm{B} / \mathrm{E} / \mathrm{S}$ observations issued from analyst teams and analyst speech portions that were asked by a colleague of the indicated analyst in I/B/E/S will be excluded from our analyses.

${ }^{8}$ According to Ljungqvist et al. (2009), analysts as well as the employing brokerage houses have the opportunity to initiate an anonymization of their forecasts.

${ }^{9}$ In relative terms, our sample contains $32,61 \%$ of the total analyst speech portions of 799,105 . This ratio is comparable to prior literature (e.g., Call et al., 2020).
} 
capital market. Cicon (2017) finds that new information in the Q\&A is rewarded by the market, underlining that the thematic difference to the management presentation is informative. We differ from Lee (2016) and Cicon (2017) by focusing on analysts' questions which are arguably the natural trigger for managers' answers. Hence, we operationalize the extent to which analysts share information in conference calls by the degree to which they add incremental information to the conference call in the Q\&A session, that is, the degree of thematic difference between each respective question and the management presentation. In line with Lee's (2016) and Cicon's (2017) findings, we argue that thematically different questions approximate analysts' sharing of thematically different information in their question, assuming that thematically different (similar) questions provide more (less) information and thematically different (similar) answers convey more (less) information. ${ }^{10}$ Given that the management has full discretion about what they like to share in the management presentation, thematically different questions can highlight important issues that the management does not want to highlight or discuss on a voluntary basis. In additional analyses, we also calculate the information sharing measure for each respective management answer to be able to provide inferences regarding the interplay of questions and answers.

Following Cicon (2017), we apply the concept of cosine modification (inverse of cosine similarity) to approximate the degree of thematic difference. Thus, we do not apply a pre-defined selection (dictionary) of specific words or word lists like the sentiment of a text (e.g., Loughran \& McDonald, 2011), but consider every word or phrase that is included in each conference call. Oftentimes, conference calls contain an operator, typically a third-party participant or an employee from the company's investor relations department, who is responsible for the

\footnotetext{
${ }^{10}$ Our definition of incremental information could also be referred to as 'new' information in the Q\&A session compared to the management presentation. In line with Cicon (2017), we define incremental information as any information which is lexically different from the management presentation, irrespectively of whether the question is regarding any e.g. key event that may be of knowledge to all analysts.
} 
intra-call organization. They welcome the participants and the listening audience to the conference call, initiate the transition from the management presentation to the Q\&A, and moderate the Q\&A. We exclude these speech portions as they do not contain any information that is relevant to answer our research question. Additionally, we limit our analysis to the speech elements of C-level executives. ${ }^{11}$

In order to reduce the dimensionality of the textual data, prior literature shows that it is rational to exclude highly frequent words ("stop words"; see Manela \& Moreira, 2017) ${ }^{12}$ and word categories that do not contain any information content with regard to the underlying research question (e.g., Lee, 2016) ${ }^{13}$. The respective term-document matrices contain the cleaned management presentation and the analysts' questions, aggregated on the analyst-level. Subsequent term-weighting is based on mono- and bigram counts for each specific conference call.

The cosine similarity $\left(\cos \operatorname{sim}_{a, i, t}\right)$ is defined as the dot product of the two resulting word count vectors of the management presentation $\left(M P_{i, t}\right)$ and each respective analyst question part $\left(Q \& A_{a, i, t}\right)$ scaled by a function of the word vectors' lengths, where $a$ refers to the analyst, $i$ to the firm, and $t$ the quarter. This score is bounded between 0 and 1 with a smaller (higher) cosine similarity indicating that the angle between both vectors is smaller (greater) and therefore the similarity between the management presentation and the specific analyst question is higher (lower). Similar to Brown and Tucker (2011), and for the ease of interpretation, we subtract the similarity score from 1 to get the cosine modification score $\left(\cos \bmod _{a, i, t}\right)$, which we

\footnotetext{
${ }^{11}$ With C-level executives, we refer to CEO, CFO, COO, CRO, CIO, and CRO. This design choice is based on the observation that oftentimes lower-level managers and investor relations employees provide comments that do not contain any information content (e.g., organizational issues). Therefore, it seems implausible to use them as a reference point for the calculation of our information sharing measure.

${ }^{12} \mathrm{We}$ use the stop word list included in the Python spaCy package. Link to spaCy package: https://spacy.io/. Furthermore, we exclude words that appear in every question of the conference call.

${ }^{13} \mathrm{We}$ use the spaCy part of speech tagger to derive word classes. The final term-document matrix only includes nouns ("NOUN"), adjectives ("ADJ"), verbs ("VERB"), and proper nouns ("PROPN"). Proper noun refers to e.g., names of cities. Link to spaCy part of speech tagger: https://spacy.io/. The decision to use only those specific word categories is derived from evidence of prior literature. Lee (2016) argues that function words (articles, conjunctions, pronouns, prepositions, and auxiliary verbs) mainly have grammatical functions and therefore do not contain any firm-specific information. They are assumed to convey information about the speaking style and as we measure the content similarity between a statement and a question, those words may naturally differ and therefore would bias the result.
} 
label as $\operatorname{Info} Q$ in the following. Hence, raising a question with a high (low) cosine modification score requires relatively more (less) information.

$$
\begin{gathered}
\cos \operatorname{sim}_{a, i, t}=\frac{M P_{i, t} \times Q \& A_{a, i, t}}{\left\|M P_{i, t}\right\|\left\|Q \& A_{a, i, t}\right\|} \\
\operatorname{Info} Q_{a, i, t}=\cos \bmod _{a, i, t}=1-\cos \operatorname{sim}_{a, i, t}
\end{gathered}
$$

As the degree of information sharing is largely dependent on the management presentation and, in relative terms, on the average amount of information sharing within the conference call, we compute abnormal levels of information sharing to be able to capture whether an analyst shares relatively more or less information compared to her peers in the same conference call. In line with prior literature (e.g., Mayew, 2008; Call et al., 2020), information sharing is captured by the abnormal degree of information sharing. We calculate abnormal information sharing by subtracting the smallest value of Info $Q_{a, i, t}$ of any analyst participating in firm $i$ 's conference call in quarter $t$ from $\operatorname{Info} Q_{a, i, t}$, scaled by the range of $\operatorname{Info} Q_{a, i, t}$ for all analysts participating in firm $i$ 's conference call in quarter $t$. Hence, this approximation is not restricted to the matched analysts but compares information sharing behavior of all participating analysts.

\section{Measurement of analysts' information endowment}

We approximate analyst ex-ante (ex-post) information endowment for a firm by the relative forecast accuracy of her last (first) forecast before (after) the conference call for this firm regarding the earnings in the following quarter. ${ }^{14}$ Our measurement of analyst's information endowment is not trying to approximate the overall ability of an analyst but rather for the quality of the underlying transitory (short-term) information set of the analyst. We assume that analysts with a higher information endowment provide a more accurate forecast for the earnings of the next quarter compared to analysts with a lower information endowment.

\footnotetext{
${ }^{14}$ We consider analysts' information endowment by analyzing the relative accuracy of their forecasts for quarter $\mathrm{t}+1$. We do not analyze the accuracy of their forecasts in quarter $t$, as this information endowment is arguably obsolete and may not be exposed to the same information hiding incentives.
} 
In line with Mayew (2008), we capture analysts' relative forecast accuracy as analysts' abnormal forecast accuracy. We calculate an analyst $a$ 's abnormal forecast accuracy as the largest forecast error $\left(F E_{a, i, t}\right)$ of any analyst providing an forecast for the quarter $t+1$ for firm $i$ in quarter $t$ less the individual analyst $a$ 's forecast error and scale this difference by the range in $F E_{a, i, t}$ for all analysts providing an forecast for the quarter $t+1$ for firm $i$ in quarter $t$. Hence, we hereby consider not only analysts who participate in the conference call but also all non-participating analysts who issue a forecast for the respective firm. The most accurate analyst is ranked with 1 whereas the least accurate is ranked with 0 .

Measuring analysts' information endowment is an empirical challenge as it is private information and not directly observable. Moreover, analysts' information endowment arguably is a multidimensional construct, containing elements such as experience, skills, and resource allocation. Thus, although we argue that our main specification of relative forecast accuracy $(A b n F A)$ is the closest approximation, we also implement additional analyst-specific variables that arguably approximate analysts' information endowment, that is analysts' relative firm-specific experience (AbnFirmExp) and their lagged participation (LagPartic). Firm-specific experience as well as the participation in the last conference call approximants a higher firms-specific knowledge which may arguably help to predict future firm performance.

\section{Chain of evidence}

As elaborated above, we expect that information sharing in questions is costly for analysts as their peers can freeride on their information advantage. To test Hypothesis H1, we regress analysts' ex-post relative forecast accuracy on their information sharing as well as their ex-ante relative forecast accuracy. To test Hypothesis $\mathrm{H} 2$ of whether analysts with a superior ex-ante information endowment share less information in their questions in conference calls, we regress our measure of information sharing on analysts' ex-ante relative forecast accuracy. We further validate our findings by including alternative measures of analysts' information endowment such as analysts' firm-specific experience and lagged participation. 
In additional analyses, we elaborate upon the mechanisms driving our main findings. First, we identify conditions that likely increase or reduce analysts' willingness to share information, that is, uncertainty, competition, and the extent to which managers present good or bad news in the management presentation.

Second, we investigate the interplay between analysts' questions and managers' answers. In particular, we examine whether an informative question also triggers an informative answer and how the interaction between informative questions and answers affects the change in analysts' absolute forecast accuracy and the overall ex-post information uncertainty. Finally, we examine whether capital markets react differently to analysts' and management's information sharing in conference calls.

\section{Consequences of information sharing}

To analyze the association between analysts' information sharing and their ex-post relative forecast accuracy (H1), we estimate OLS regression equation (1):

$$
A b n F A_{a, i, t+1}=\gamma \text { AbnInfo } Q_{a, i, t}+\mathbf{X}_{\mathrm{a}, \mathrm{i}, \mathrm{t}} \boldsymbol{\beta}+\mathbf{Y}_{\mathrm{i}, \mathrm{t}} \boldsymbol{\delta}+\mu_{i}+\pi_{k}+\sigma_{t}+\varepsilon_{a, i, t}
$$

where $a$ is an index for the analyst, $i$ an index for the firm, $t$ an index for the quarter, $k$ an index for the year. $\mu_{i}$ captures firm fixed effects. ${ }^{15} \pi_{k}$ refers to year fixed effects to account for differences over time. $\sigma_{t}$ captures quarter fixed effects to account for differences between quarters. We estimate the regression model with robust standard errors clustered at the analyst level. According to the expectations raised in Hypothesis H1, we expect $\gamma$ to be negative, as we predict that sharing information in the question enables peer analysts to freeride on the disclosed information, thus reducing the focal analyst's information advantage.

\footnotetext{
${ }^{15} \mathrm{We}$ include firm fixed effects to account for unobservable differences in question phrasing across firms. This decision is based on Abraham and Bamber (2017) who conclude that the Q\&A session is an interaction ritual with basic rules of conduct, which are arguably firm-specific.
} 
$\boldsymbol{X}_{a, i, t}$ represents a vector of control variables related to analysts' characteristics and their intra-conference call questioning. In line with Mayew (2008), analyst characteristics contain AbnFA, AbnRec, Abn\#Forc, Abn\#Comp, Abn\#Ind, AbnFirmExp, AbnGenExp, AbnRecHoriz, AbnSizeBrok, LagPartic, and PosQuestion. We control for these variables as we expect that those characteristics also influence analyst's ex-post relative forecast accuracy.

$A b n F A$ refers to analyst's relative forecast accuracy before the conference call. AbnRec is analyst's abnormal level of her outstanding stock recommendation, where a value of 1 indicates that the analyst is the most favorable of all analysts in terms of the outstanding stock recommendation. Abn\#Forc approximates analyst's abnormal forecast frequency for any firm within the last 12 months prior to the conference call. Abn\#Comp (Abn\#Ind) measures the number of different companies (industries) an analyst covered within 12 months prior to the conference call. AbnFirmExp (AbnGenExp) refers to an analyst's firm-specific (general) experience and is measured in years. AbnRecHoriz measures the horizon of the outstanding stock recommendation as the difference between the conference call date and the issuance date of the stock recommendation. AbnSizeBrok approximates the analyst's brokerage house size as the total number of analysts employed in the 12 months before the conference call. LagPartic is an indicator variable that turns 1 if an analyst was also allowed to ask a question in the last conference call, 0 otherwise. PosQuestion indicates the sequential number of analyst's questions to control for any management favorability that is signaled by granting more favorable analysts earlier question turns.

$\boldsymbol{Y}_{i, t}$ represents a vector of control variables related to the information environment of firm $i$ in quarter $t$, which may influence the information sharing behavior of analysts in conference calls. We follow Hope and Wang (2018) and include the control variables Size, BTM, Leverage, Coverage, Beat, Surprise, $\triangle R O A$, and Loss.

Size is the natural logarithm of total assets in thousands. Prior studies found that information asymmetries decrease with increasing size (Glosten \& Harris, 1988; Leuz, 2003). BTM 
is the book value of equity divided by the market value of equity and represents a proxy for growth opportunities or risk. For high growth or risk firms, information asymmetries are regarded to be higher. Leverage is the leverage share of equity defined as the sum of long-term debt and short-term liabilities divided by common equity. Firm-investor-asymmetries are negatively related to leverage, as firms with higher leverage are regarded to be monitored more closely. Coverage is the natural logarithm of the average number of forecasts regarding next quarters earnings before the conference call, and thus controls for variances in the competitiveness of the information environment for analysts (Hong \& Kacperczyk, 2010). Beat is an indicator variable that is equal to 1 if the firm's reported earnings exceed the analysts' consensus earnings forecast, and 0 otherwise. Prior literature shows that firms that beat the consensus experience a decrease in information asymmetry (Brown et al., 2009). Surprise is the difference between quarterly EPS and the mean consensus analyst forecast. It is intended to control for the amount of 'new' information provided to the market by announced earnings (Bushee et al., 2010). $\triangle R O A$ is the change in the return on assets between the current and the past quarter and controls for firm's financial performance change as prior studies have shown that firm-investor information asymmetries are more likely to increase with performance variability (Brown \& Hillegeist, 2007). Loss is an indicator variable that is equal to 1 if the firm is reporting negative earnings, and 0 otherwise. This variable controls for managers' tendency to provide more insights and supplemental disclosures when disclosing bad news (Baginski et al., 2004) as well as for loss-induced changes in analysts' information sharing behavior.

\section{Determinants of information sharing}

To analyze the association between analysts' ex-ante relative forecast accuracy and their information sharing (H2), we estimate OLS regression (2):

$$
\begin{aligned}
\operatorname{AbnInfo}_{a, i, t}= & \gamma \operatorname{AbnFA}_{a, i, t-1}+\rho \text { AbnFirmExp } \\
& +\mu_{i, i, t}+\lambda \pi_{k}+\sigma_{t}+\varepsilon_{a, i, t}
\end{aligned}
$$


Similar to our regression model to test Hypothesis H1, we include firm $\left(\mu_{i}\right)$, year $\left(\pi_{k}\right)$, and quarter $\left(\sigma_{t}\right)$ fixed effects. We estimate the regression model with robust standard errors clustered at the analyst level. Following prior literature (e.g., Mayew, 2008; Call et al., 2020), our determinants model assumes that information sharing is a function of analysts' characteristics as well as their intra-conference call questioning $\left(\boldsymbol{X}_{a, i, t}\right.$ excluding AbnFirmExp $p_{a, i, t}$ and LagPartic $\left._{a, i, t}\right)$ and the characteristics of firms' information environment $\left(\boldsymbol{Y}_{i, t}\right)$.

In line with Hypothesis $\mathrm{H} 2$, we expect $\gamma$ to be negative, indicating that analysts with a higher information endowment share less information in their questions in conference calls. Consistently, we expect $\rho$ and $\lambda$ to be negative, suggesting that analysts with more firm experience and analysts who participated in the previous conference call of the firm share less information. We sequentially include these analyst characteristics in the regression model and finally run the full model, as we understand information advantages as a multi-dimensional construct that can be approximated by analysts' accuracy before the call, their firm-specific experience, and their participation in previous earnings conference calls.

\section{$\underline{\text { Descriptive statistics }}$}

Table 2 reports the descriptive statistics of the variables. Panel A provides an overview about the analyst variables measured on the analyst-speech portion level, whereas Panels B and C capture the variables measured on the (call)firm-level.

[Please insert Table 2 here]

Compared to all questions raised in the included conference calls, the analyst-speech portions we were able to match contain above average information with a mean vale of 0.52 . The arguably high standard deviation of 0.33 provides slight support for our expectations regarding the transitory nature of the quality of analysts' information set. The abnormal forecast 
accuracy of 0.56 implies that the participating analysts provide relatively more accurate forecasts compared to all analysts who follow the firm. Furthermore, participating analysts maintain a slightly positive recommendation indicated by the mean of AbnRec of 0.51 . These observations are consistent with the findings by Mayew et al. (2013), suggesting that especially analysts with superior information and more favorable views participate in conference calls. With respect to the alternative approximations of analysts' information endowment, the participating analysts have an abnormal firm-specific experience of 0.47 and participated in 61 out of 100 times in the firm's last conference call.

Moving to the call- and firm-level variables (Panels B and C), on average 7.76 analysts participate in the call. The average information uncertainty approximated by the dispersion in outstanding analyst forecasts regarding the next quarter's earnings declines by 0.01 around the conference call. This is in line with the general assumption that conference calls are an important disclosure setting that provides useful information to analysts. Each firm is covered by 10.70 analysts and beats the analysts' consensus forecast in 63 out of 100 times, on average by 0.03 EPS.

\section{RESULTS}

\section{$\underline{\text { Correlation analysis }}$}

Table 3 reports the Pearson correlations among the variables used in the regression analyses. In line with our expectations, we find a statistically significant negative association between analyst's relative forecast accuracy before as well as after the conference call and their intra-call information sharing (both $\mathrm{p}$-values $<0.1$ ). This result already provides first evidence of a negative association between analysts' information sharing and their ex-post relative forecast accuracy (H1). Moreover, it indicates a negative association between analysts' ex-ante relative forecast accuracy and their information sharing during the call (H2). Furthermore, with regard 
to our alternative proxies for analysts' information endowment, higher firm-specific experience as well as participation in the past conference call are associated with lower information sharing (both p-values < 0.01).

[Please insert Table 3 here]

\section{$\underline{\text { Regression results }}$}

Table 4 reports the results for the association between analysts' information sharing and their ex-post relative forecast accuracy.

[Please insert Table 4 here]

We find a negative and statistically significant (p-value $<0.01)$ association between relative information sharing (AbnInfo $Q)$ and analysts' abnormal forecast accuracy after the conference call. This finding supports Hypothesis H1, suggesting that information sharing in conference calls is negatively associated with analysts' ex-post relative information endowment. Furthermore, we find a positive and statistically significant (p-value $<0.01$ ) association between analysts' relative forecast accuracy before the conference call $\left(A b n F A_{t}\right)$ and analysts' relative forecast accuracy after the conference call. Hence, analysts that already have a relatively accurate outstanding forecast tend to issue relatively more accurate forecasts after the conference call. We also find positive and statistically significant coefficients ( $\mathrm{p}$-value $<0.01$ ) for our alternative information endowment measures of firm-specific experience (AbnFirmExp) and past conference call participation (LagPartic).

Table 5 reports the results for the association between analysts' ex-ante information endowment and their information sharing during the conference call. We first look at our information endowment variables individually before we combine them in a full model to control for any correlation between our proxies for analysts' information endowment. For analysts' abnormal forecast accuracy before the conference call (Table 5 column $1 ; A b n F A$ ), we find a positive and statistically significant ( $\mathrm{p}$-value $<0.05$ ) coefficient, suggesting that analysts with a higher relative forecast accuracy ex-ante tend to share less information in their questions. 
Furthermore, our analyses regarding analysts' firm-specific experience (AbnFirmExp) and past conference call participation (LagPartic) show consistent results (p-values $<0.01$ ). By estimating the comprehensive model to control for any correlation between our proxies for analysts' information endowment, we find similar results. All three information sharing variables (AbnFA, AbnFirmExp, LagPartic) have a significant explanatory power (F-test value: 126.39, p-value < 0.01). Furthermore, variations in the n-gram specification and term-weightingscheme result in similar results (untabulated). ${ }^{16}$ Overall, these results collectively support Hypothesis $\mathrm{H} 2$ that analysts with a higher information endowment share less information in their questions in conference calls, suggesting that superior analysts care more about their relative forecast accuracy.

[Please insert Table 5 here]

\section{ADDITIONAL ANALYSES}

\section{Mechanism analysis: Determinants of information sharing}

In the following, we elaborate upon the mechanisms behind our main findings. In particular, we expect the degree of competition among analysts to decrease analysts' willingness to share information in conference calls as it allows freeriding of peers and thus likely endangers information advantages. Our measure of analyst competition is based on the theoretical notion that increased group consistency leads to more competitive environments. If analysts consistently compete against the same group of analysts over multiple periods, they arguably have stronger incentives to reduce peers' freeriding to maintain their information endowment. This may be important to acquire and keep their firm-specific client business. Competition is measured as

\footnotetext{
${ }^{16}$ These results show that the observed results are not driven by the specification of our information sharing measure, increasing the internal validity of our analysis. This variation analysis is motivated by prior literature that collectively emphasizes the importance of term-weighting in information retrieval (e.g., Salton and Buckley (1988).
} 
the average last quarter $(t-1)$ firm-specific conference participation of all participating analysts of the conference call in period $t$.

Moreover, we examine the association between analysts' ex-ante information uncertainty and their information sharing in conference calls. Following our line of argumentation described in the hypotheses development, we expect that analysts share more information in their questions during conference calls, the more information they need in order to generate accurate earnings forecasts, that is, the higher the information uncertainty before the conference call. In line with prior literature, we define information uncertainty (Uncertainty) as the dispersion (standard deviation) of analysts' forecasts before the conference call in quarter $t$ for quarter $t+1$ (e.g., Diether et al., 2002).

Additionally, we examine whether analysts' information sharing depends on the extent to which the management discloses good or bad news in the management presentation, which we capture by the tone in the management presentation. We expect the degree of information sharing to decrease with the tone of the presented information in the management presentation. Our expectation is based on the assumption that analysts tend to ask questions that are less related to the management presentation (i.e., information seeking questions) if the contained information is more negative. ToneMP is calculated as the difference between positive and negative word counts scaled by the number of words of the management presentation. ${ }^{17}$ We perform these analyses at the conference call level since the independent variables are measured at the conference call level. We estimate the regression model with firm fixed effects and robust standard errors clustered at the firm-level. We present the results in Table 6.

\section{[Please insert Table 6 here]}

We find a negative and statistically significant ( $\mathrm{p}$-value < 0.01$)$ coefficient on Competition, a positive and statistically significant ( $\mathrm{p}$-value $<0.01)$ coefficient on Uncertainty, and a

\footnotetext{
${ }^{17}$ In line with prior literature, we measure tone by the word list of Loughran and McDonald (2011).
} 
negative and statistically significant (p-value < 0.01) coefficient on ToneMP (Table 6, columns 1 to 3). The results are similar for the full regression model that includes all variables jointly (Table 6, column 4). This indicates that analysts share less information in conference calls when the competition among the participating analysts is higher, share more information when the information uncertainty is higher, and share less information when the management presents good news.

Interplay between analysts' questions and managers' answers: Managers' response to information sharing in analysts' questions

Next, we explore the interplay between analysts and managers during the Q\&A section. In particular, we examine the characteristics of managers' answers in response to information sharing in analysts' questions. This analysis is important as we expect individual and peer analysts to mainly learn from managers' answers to analysts' questions rather than to learn from analysts' questions themselves. We hereby assume that individual analysts do not gain more information from managers' answers to their questions than their peer analysts. This assumption is consistent with anecdotal evidence gained from interviews with analysts, indicating that analysts do not face difficulties in understanding questions from peers as well as the respective answers from the management in conference calls.

First, we investigate whether information sharing in the question leads to more information sharing in the answer. We hereby expect that more informative questions lead to more informative answers. This analysis extends the evidence provided by Cicon (2017) who solely examines the degree of thematic difference between the management's answers and the management's presentation. He finds that a higher degree of thematic difference is associated with a positive market response, indicating that the market rewards management's efforts to provide new information in the Q\&A session. Hence, providing evidence that the degree of thematic 
difference is triggered by the analysts' questions will increase our understanding of the dynamics in conference calls. We present the findings of this analysis in Table 7. We run the analysis on the analyst-level with firm fixed effects and clustered standard errors at analyst level.

[Please insert Table 7 here]

Our results show that information sharing in questions leads to a more informative answers from the management (p-value $<0.01$, Table 7 Panel A column 1). This result underlines the interrelation between question and answer and suggests that the extent to which managers share 'new' information is significantly influenced by the analysts' questions.

To further increase our understanding of this interplay, we investigate the moderating role of the questions' abnormal tone (AbnToneQ), measured by the Loughran and McDonald (2011) word list, and abnormal specificity (Abn\#Numbers), approximated by the usage of monetary or percentage numbers (Gow et al., 2021). For the tone analysis (Table 7 Panel A, column 2), we find a negative and statistically significant coefficient on AbnTone $Q$ (p-value $<0.01$ ) as well as for the interaction with $A b n I n f o Q$ (p-value < 0.01). Comparably to Haag et al. (2021), this means that the management's information sharing increases with the negativity of the respective question and the association gets stronger when analysts address thematic content that was not discussed in the management presentation. Furthermore, we find a negative and statistically significant coefficient on Abn\#Numbers (p-value < 0.01) and its interaction with AbnInfo $Q$ ( $\mathrm{p}$-value $<0.01$ ). This implies that the management's information sharing is decreasing if analysts ask questions with a high degree of specificity.

Second, we apply more general concepts that approximate the management's willingness to provide information in the answer. Kothari et al. (2009) show that managers are less willing to disclose unfavorable (bad) news in comparison to favorable (good) news. Translated into our setting, the management's willingness to provide information will be higher (lower) if the question addresses a favorable (unfavorable) topic. Largely based on Call et al. (2020), we approximate management's willingness to provide information by the abnormal answer length 
(Abn\#WordsA), measured by the number of words in the answer, and the abnormal number of answers (Abn\#Answers), approximated by the sum of speaker changes within the management's answer ${ }^{18}$.

In Table 7 Panel B, we find negative and statistically significant coefficients (p-values $<0.01$ ) for both proxies (Abn\#WordsA and Abn\#Answers), supporting our expectation that informative questions are negatively associated with the management's willingness to provide information and thus likely address topics the management is reluctant to talk about. This finding is likely explained by the argument that managers would have already provided the information the analyst is asking for in the presentation session if they were willing to disclose this information voluntarily.

\section{Information content and the signal of information sharing in question and answer}

The final set of analyses deals with the consequences of analysts' and managers' information sharing in conference calls. In particular, we examine whether information sharing is associated with an increase in analysts' absolute information endowment and a reduction in overall information uncertainty after the conference call. In other words, these analyses address the questions of whether information sharing in questions increases the analyst's absolute forecast accuracy and how information sharing affects the distribution of outstanding EPS forecasts. We expect analysts to increase their information endowment in absolute terms when they share information in their questions. We approximate the change in the absolute forecast accuracy $(\triangle F A)$ as the inverse difference between the forecast error after the conference $\left(F E_{t+1}\right)$ and the forecast error before the conference call $\left(F E_{t}\right)$ regarding the earnings in $t+1$. Hence, an increase in $\triangle F A$ represents an improvement in absolute forecast accuracy. Furthermore, we investigate

\footnotetext{
${ }^{18}$ Oftentimes, more than one firm representative provides an answer to a single question. Besides other reasons, this behavior can be observed whenever a firm representative wants to follow-up on the comments of the first (or $n^{\text {th }}$ ) respondent to an analyst question. We argue that this answering behavior serves as a credible proxy for management's willingness to provide information. Hence, a higher number of answers indicates a higher willingness to provide information.
} 
the consequences of information sharing on the ex-post information uncertainty (Uncertain$\left.t y_{t+1}\right)$. We expect information uncertainty to decrease as information sharing increases. We present the findings in Table 8 .

[Please insert Table 8 here]

We find a negative and statistically significant ( $\mathrm{p}$-value $<0.01)$ association between analysts' relative forecast accuracy ex-ante $\left(A b n F A_{t}\right)$ and their change in absolute forecast accuracy, suggesting that relatively more accurate analysts experience a decrease in absolute forecast accuracy when they actively participate in a conference call. This finding underscores the presence of mean reversion in analysts' forecast accuracy, that is, conference calls partially offset information advantages. More importantly, we find that neither an informative question $(A b n I n f o Q)$ nor answer $(A b n I n f o A)$ has a direct effect on the change in absolute forecast accuracy. However, if we interact those three variables $\left(A b n I n f o Q \times A b n I n f o A \times A b n F A_{t}\right)$, we find a positive and statistically significant $(\mathrm{p}$-value $<0.05)$ coefficient. This finding suggests that analysts with a relatively high information endowment, who ask an informative question and receive an informative answer, are able to improve their absolute forecast accuracy, underscoring that information sharing is not only harmful for superior analysts but also provides benefits in terms of their absolute forecast accuracy.

With regard to the analysis regarding the ex-post information uncertainty, we find a negative and statistically significant (p-value $<0.01)$ association between analysts' abnormal forecast accuracy $\left(A b n F A_{t}\right)$ and the information uncertainty after the conference calls. This implies that the active participation of analysts with a high relative forecast accuracy decreases information uncertainty. Furthermore, we find a negative and statistically significant (p-value $<0.01)$ association between the three-way interaction of information sharing in questions, information sharing in answers, and analysts' relative forecast accuracy $\left(A b n I n f o Q \times A b n I n f o A \times A b n F A_{t}\right)$ and ex-post uncertainty, indicating that especially the high information sharing questions and answers from analysts' with a high information endowment 
reduce the information uncertainty after a conference call. This finding can be interpreted as evidence of peer learning in conference calls and highlights the importance for analysts with a higher information endowment to be mindful in safeguarding their information advantage.

Additionally, we investigate how capital markets respond to the interplay between information sharing in questions and answers. This analysis is motivated by the evidence provided by Cicon (2017), who solely focuses on the management's answers. We extend his findings by providing a more comprehensive picture of information sharing as we do not only examine capital market responses to managers' answers but also analysts' questions and their interplay. While it is obvious that informative management's answers are rewarded by capital markets, the implications of information sharing in questions may be twofold: First, informative questions may be interpreted as a positive signal as the analyst's activity reduces investors' information awareness as well as acquisition costs (e.g., Chen et al., 2016). Second, analysts' information seeking activity may also send a negative signal as it may indicate that the management intentionally tried to hide information that likely represents bad news. Following Kothari et al. (2009), it seems reasonable to assume that the management tries to especially hide bad information. We approximate the capital market response as the size-decile adjusted return during a $[0,+1]$ trading window around the conference call date $(C A R[0,+1])$. We present our findings in Table 9.

[Please insert Table 9 here]

We find a positive and statistically significant $(\mathrm{p}$-value $<0.01)$ market response to the average level of information sharing in the management's answers (AvgInfoA). This finding is in line with the evidence provided by Cicon (2017), suggesting that the capital market interprets information sharing ('new' information) in the answers as a positive signal. In contrast, we find a negative and statistically significant $(\mathrm{p}$-value $<0.01)$ market response to the average information sharing in the analysts' questions (AvgInfoQ), supporting our expectation that infor- 
mation sharing in questions may be interpreted as an information seeking activity. The interaction of information sharing in questions as well as answers (AvgInfo $Q \times A v g \operatorname{InfoA})$ is associated with a negative and statistically significant $(\mathrm{p}$-value $<0.1)$ capital market reaction. This finding suggests that information sharing in the answer is not unconditionally viewed positively by capital markets. If an informative answer follows an informative question, the capital market will interpret the co-occurrence as a negative signal. Since our prior analyses show that a large part of information sharing in the management's answers is determined by analysts' information sharing in their questions, we interpret this finding as further evidence that informative questions actually address critical topics.

\section{Conclusion}

We study whether analysts with superior information selectively share information in their questions during conference calls. Prior research suggests that analysts have an incentive to reveal information in their questions as sharing information is typically associated with informative management responses, likely increasing the accuracy of their earnings forecasts (in line with Minson et al., 2018; Haag et al., 2021). However, we expect analysts to also face cost when sharing information in their questions, that is, analysts' relative forecast accuracy decreases. Consequently, in line with Verrecchia (1982) and Diamond (1985), we expect analysts with superior information to be reluctant to share information in their questions as peer analysts may freeride on their information, potentially reducing superior analysts' information advantages.

Using 260,589 analysts' speech portion of quarterly conference calls of all listed U.S. firms in the time-period 2008 to 2020, we document that analysts' relative forecast accuracy decreases when they share information in their questions during conference calls. Consistently, we provide evidence that analysts with a higher ex-ante information endowment share less information in their questions, as they arguably intend to safeguard their information advantage. In additional analyses, we explore the underlying mechanism driving our findings. First, we 
show that analysts' information sharing increases (decreases) with the ex-ante information uncertainty (competition), suggesting that analysts' strategically make use of information sharing to acquire information or hinder peer learning. Second, we explore the interplay between analyst questions and management answers. We find that managers provide more informative answers when analysts ask more informative questions. This finding especially holds when analysts phrase their questions negatively or are less specific in their questions. We also find that informative questions are associated with shorter answers and a lower number of answers, suggesting that managers are reluctant to answer these questions in detail.

Third, we examine the consequences of analysts' information sharing in questions on their absolute forecast accuracy and the overall analysts' ex-post uncertainty. We document that analysts' absolute forecast accuracy (overall uncertainty) increases (decreases) when superior analysts ask informative questions that are associated with informative answers, underscoring the positive implications of superior analysts' information sharing at the individual level and its positive externalities. Finally, we explore capital market reactions to informative questions and answers. We find that capital markets positively respond to informative managers' answers and negatively to analysts' questions. Moreover, we find that capital markets discount managers' information sharing in answers when it is triggered by analysts, i.e., by analysts' asking informative questions. This analysis suggests that informative questions actually address critical topics.

Our study is subject to limitations. First, our measurement of incremental information shared in analysts' questions (managers' answers) contains only the lexical and not the semantical difference of each respective analyst's question (management's answer) to the management presentation. Thus, if an analyst (manager) uses different words in her question (his answer) as the management in the presentation section, we would categorize that question (answer) as incrementally informative. We try to alleviate this concern by including bigrams in the calculation of the cosine modification score. Additionally, our relative measure of deviation 
should also help us in this regard as we compare analysts that differ more strongly than others. Moreover, we argue that this limitation does not systematically distort the similarity measure as the business language seems to be standardized and analysts arguably have no incentive to deviate.

Second, there may be an alternative motivation for analysts to share less information during conference calls, that is, analysts share relatively less information during conference calls as they have a private communication channel with the management and are therefore less dependent to use the conference call as information acquisition channel. However, this argument does not affect superior analysts' incentives to hide information in conference calls to mitigate peers' freeriding opportunities, which is at center-stage in our study. Accordingly, we would expect superior analysts' information sharing to further decrease the more private access they have to the firm's management, reducing the need to share information during conference calls to acquire information.

This study introduces the role of strategic questioning induced by the analysts' information endowment as a determinant of conference calls' informativeness. We contribute to the literature on strategic interactions between analysts and managers during conference calls (e.g., Mayew, 2008; Mayew et al., 2020) by examining the strategic information exchange within the group of analysts. 


\section{APPENDIX}

Appendix 1: Variable definitions

\begin{tabular}{|c|c|}
\hline Label & Definitions \\
\hline \multicolumn{2}{|r|}{ Analyst variables } \\
\hline Info $Q$ & $\begin{array}{l}\text { Analyst } a^{\prime} \text { 's information sharing during firm } i \text { 's conference call in quarter } t \text {, } \\
\text { measured the as cosine modification score, i.e. inverse of cosine similarity } \\
\text { between management presentation and analyst } a \text { 's question. }\end{array}$ \\
\hline$A b n I n f o Q$ & $\begin{array}{l}\text { Abnormal information sharing of analyst } a \text { during firm } i \text { 's conference call } \\
\text { in quarter } t \text {, calculated as Info } Q_{a, i, t} \text { less the smallest Info } Q_{a, i, t} \text { for any analyst } \\
\text { participating in firm } i \text { 's conference call in quarter } t \text {, with this difference } \\
\text { scaled by the range in Info } Q_{a, i, t} \text { for all analysts participating in firm } i \text { 's con- } \\
\text { ference call in quarter } t \text {. }\end{array}$ \\
\hline InfoA & $\begin{array}{l}\text { Measures the management's relative information sharing in their answer to } \\
\text { analyst } a \text { 's question, measured as cosine modification score, i.e. inverse of } \\
\text { cosine similarity between management presentation and the management's } \\
\text { answer }\end{array}$ \\
\hline AbnInfoA & $\begin{array}{l}\text { Abnormal information sharing of the management in their answer to ana- } \\
\text { lyst } a \text { 's question during firm } i \text { 's conference call in quarter } t \text {, calculated as } \\
\text { Info } A_{a, i, t} \text { less the smallest Info } A_{a, i, t} \text { for any answer to analysts' questions } \\
\text { during firm } i \text { 's conference call in quarter } t \text {, with this difference scaled by } \\
\text { the range in Info } A_{a, i, t} \text { for all answers to analysts' questions during firm } i \text { 's } \\
\text { conference call in quarter } t \text {. }\end{array}$ \\
\hline$F E_{t}$ & $\begin{array}{l}\text { Analyst } a \text { 's absolute forecast error for firm } i \text { before the conference call in } \\
\text { quarter } t \text { regarding EPS in quarter } t+1 \text {. }\end{array}$ \\
\hline$A b n F A_{t}$ & $\begin{array}{l}\text { Abnormal absolute forecast accuracy of analyst } a \text { 's EPS forecast for firm } i \\
\text { in quarter } t \text { regarding EPS in quarter } t+1 \text {, calculated as the largest } F E_{a, i, t} \text { of } \\
\text { any analyst providing an EPS forecast for the quarter } t+1 \text { for firm } i \text { in quar- } \\
\text { ter } t \text { less } F E_{a, i, t} \text {, with this difference scaled by the range in } F E_{a, i, t} \text { for all } \\
\text { analysts providing an EPS forecast for the quarter } t+l \text { for firm } i \text { in quarter } \\
t \text {. }\end{array}$ \\
\hline$F E_{t+1}$ & $\begin{array}{l}\text { Analyst } a \text { 's absolute forecast error for firm } i \text { after the conference call in } \\
\text { quarter } t+1 \text { regarding EPS in quarter } t+1 \text {. }\end{array}$ \\
\hline$A b n F A_{t+1}$ & $\begin{array}{l}\text { Abnormal absolute forecast accuracy of analyst } a \text { 's EPS forecast for firm } i \\
\text { in quarter } t+1 \text { regarding EPS in quarter } t+1 \text {, calculated as the largest } F E_{a, i, t} t \\
\text { of any analyst providing an EPS forecast for the quarter } t+1 \text { for firm } i \text { in } \\
\text { quarter } t+1 \text { less } F E_{a, i, t} \text {, with this difference scaled by the range in } F E_{a, i, t} \text { for } \\
\text { all analysts providing an EPS forecast for the quarter } t+1 \text { for firm } i \text { in quar- } \\
\text { ter } t+1 \text {. }\end{array}$ \\
\hline$\triangle F A$ & $\begin{array}{l}\text { Analyst } a \text { 's change in absolute forecast error for firm } i \text { around the confer- } \\
\text { ence call in quarter } t \text { regarding EPS in quarter } t+1 \text {, calculated as the inverse } \\
\text { difference between } F E_{a, i, t+1} \text { and } F E_{a, i, t .}\end{array}$ \\
\hline
\end{tabular}




\begin{tabular}{|c|c|}
\hline $\operatorname{Rec}$ & $\begin{array}{l}\text { Analyst } a \text { 's outstanding stock recommendation for firm } i \text { before the confer- } \\
\text { ence call in quarter } t \text {, where } 1 \text { indicates strong sell and } 5 \text { indicates strong } \\
\text { buy. }\end{array}$ \\
\hline AbnRec & $\begin{array}{l}\text { Abnormal stock recommendation of analyst } a \text { for firm } i \text { in quarter } t \text {, calcu- } \\
\text { lated as } R e c_{a, i, t} \text { less the smallest } R e c_{a, i, t} \text { for any analyst following firm } i \text { in } \\
\text { quarter } t \text {, with this difference scaled by the range in } \operatorname{Rec}_{a, i, t} \text { for all analysts } \\
\text { following firm } i \text { in quarter } t \text {. }\end{array}$ \\
\hline \#Forc & $\begin{array}{l}\text { Analyst } a \text { 's number of quarterly EPS forecasts in quarter } t \text {, calculated as } \\
\text { the overall number EPS forecasts by analyst } a \text { for any firm in the } 12 \text { months } \\
\text { prior to the conference call of firm } i \text { in quarter } t \text {. }\end{array}$ \\
\hline Abn\#Forc & $\begin{array}{l}\text { Abnormal forecast frequency of analyst } a \text { in quarter } t \text {, calculated as } \\
\# F \text { orca,i,t less the smallest } \# F \text { orca,i,t for any analyst following firm } i \text { in quar- } \\
\text { ter } t \text {, with this difference scaled by the range in } \# F \text { orca,i,t for all analysts } \\
\text { following firm } i \text { in quarter } t \text {. }\end{array}$ \\
\hline \#Comp & $\begin{array}{l}\text { Analyst } a \text { 's number of firms covered in the } 12 \text { months prior to the confer- } \\
\text { ence call of firm } i \text { in quarter } t \text {. }\end{array}$ \\
\hline Abn\#Cотр & $\begin{array}{l}\text { Abnormal number of firms covered of analyst } a \text { in quarter } t \text {, calculated as } \\
\# F \text { orc }{ }_{a, i, t} \text { less the smallest } \# F \text { orc } a, i, t \text { for any analyst following firm } i \text { in quar- } \\
\text { ter } t \text {, with this difference scaled by the range in } \# F \text { orca,i,t for all analysts } \\
\text { following firm } i \text { in quarter } t \text {. }\end{array}$ \\
\hline \#Ind & $\begin{array}{l}\text { Analyst } a \text { 's number of two-digit SIC industries covered in the } 12 \text { months } \\
\text { prior to the conference call of firm } i \text { in quarter } t \text {. }\end{array}$ \\
\hline Abn\#Ind & $\begin{array}{l}\text { Abnormal number of two-digit SIC industries covered of analyst } a \text { in quar- } \\
\text { ter } t \text {, calculated as \#Forc } a, i, t \text { less the smallest \#For } c_{a, i, t} \text { for any analyst fol- } \\
\text { lowing firm } i \text { in quarter } t \text {, with this difference scaled by the range in } \\
\text { \#Forc } a, i, t \text { for all analysts following firm } i \text { in quarter } t \text {. }\end{array}$ \\
\hline FirmExp & $\begin{array}{l}\text { Analysts } a \text { 's firm experience for firm } i \text { in quarter } t \text {, calculated as the differ- } \\
\text { ence between the conference call date for firm } i \text { in quarter } t \text { and the date of } \\
\text { the first forecast issued by analyst } a \text { for firm } i \text {, divided by } 365 \text {. }\end{array}$ \\
\hline AbnFirmExp & $\begin{array}{l}\text { Abnormal firm experience of analyst } a \text { for firm } i \text { in quarter } t \text {, calculated as } \\
\text { FirmExpa,i,t less the smallest FirmExpa,i,t for any analyst following firm } i \text { in } \\
\text { quarter } t \text {, with this difference scaled by the range in FirmExp } \text { exi,i, }_{\text {for all an- }} \\
\text { alysts following firm } i \text { in quarter } t \text {. }\end{array}$ \\
\hline GenExp & $\begin{array}{l}\text { Analysts } a \text { 's general experience in quarter } t \text {, calculated as the difference } \\
\text { between the conference call date for firm } i \text { in quarter } t \text { and the date of the } \\
\text { first forecast issued by analyst } a \text { for any firm, divided by } 365 \text {. }\end{array}$ \\
\hline AbnGenExp & $\begin{array}{l}\text { Abnormal general experience of analyst } a \text { in quarter } t \text {, calculated as } \\
\text { GenExpa,i,t less the smallest GenExp } \operatorname{Eati,t}_{\text {for any analyst following firm } i \text { in }} \\
\text { quarter } t \text {, with this difference scaled by the range in GenExpa,i,t for all ana- } \\
\text { lysts following firm } i \text { in quarter } t \text {. }\end{array}$ \\
\hline
\end{tabular}




\begin{tabular}{|c|c|}
\hline RecHor & $\begin{array}{l}\text { Analyst } a \text { 's outstanding stock recommendation horizon for firm } i \text { quarter } t \text {, } \\
\text { calculated as the difference between the conference call date for firm } i \text { in } \\
\text { quarter } t \text { and the date of analyst } a \text { 's outstanding recommendation as of the } \\
\text { conference call date for firm } i \text { in quarter } q \text {, divided by } 365 \text {. }\end{array}$ \\
\hline AbnRecHor & $\begin{array}{l}\text { Abnormal outstanding stock recommendation horizon of analyst } a \text { for firm } \\
i \text { in quarter } t \text {, calculated as RecHor } r_{a, i, t} \text { less the smallest RecHor } r_{a, i, t} \text { for any } \\
\text { analyst following firm } i \text { in quarter } t \text {, with this difference scaled by the range } \\
\text { in RecHor } r_{a, i, t} \text { for all analysts following firm } i \text { in quarter } t \text {. }\end{array}$ \\
\hline SizeBrok & $\begin{array}{l}\text { Analyst } a \text { 's brokerage house size in quarter } t \text {, calculated as the total number } \\
\text { of analysts employed by the brokerage house of analyst } a \text { in the } 12 \text { months } \\
\text { prior to the conference call for firm } i \text { in quarter } t \text {. }\end{array}$ \\
\hline AbnSizeBrok & $\begin{array}{l}\text { Abnormal brokerage house size of analyst } a \text { in quarter } t \text {, calculated as } \\
\text { SizeBroka,i,t less the smallest SizeBroka,i,t for any analyst following firm } i \text { in } \\
\text { quarter } t \text {, with this difference scaled by the range in SizeBroka,i,t for all an- } \\
\text { alysts following firm } i \text { in quarter } t \text {. }\end{array}$ \\
\hline$\#$ Words $Q$ & $\begin{array}{l}\text { Length of analyst } a \text { 's question during firm } i \text { 's conference call in quarter } t \text {, } \\
\text { measured as the number of words of the question. }\end{array}$ \\
\hline Abn\#Words $Q$ & $\begin{array}{l}\text { Abnormal length of analyst } a \text { 's question during firm } i \text { 's conference call in } \\
\text { quarter } t \text {, calculated as \#Words } Q_{a, i, t} \text { less the smallest \#Words } Q_{a, i, t} \text { for any } \\
\text { analyst participating in firm } i \text { 's conference call in quarter } t \text {, with this differ- } \\
\text { ence scaled by the range in \#Words } Q_{a, i, t} \text { for all analysts participating in firm } \\
i \text { 's conference call in quarter } t \text {. }\end{array}$ \\
\hline \#WordsA & $\begin{array}{l}\text { Length of the answer to analyst } a \text { 's question during firm } i \text { 's conference call } \\
\text { in quarter } t \text {, measured as the number of words of the answer. }\end{array}$ \\
\hline Abn\#WordsA & $\begin{array}{l}\text { Abnormal length of the management's answer to analyst } a \text { 's question dur- } \\
\text { ing firm } i \text { 's conference call in quarter } t \text {, calculated as \#Words } A_{a, i, t} \text { less the } \\
\text { smallest \#Words } A_{a, i, t} \text { for any analyst participating in firm } i \text { 's conference call } \\
\text { in quarter } t \text {, with this difference scaled by the range in \#Words } A_{a, i, t} \text { for all } \\
\text { answers to analysts' questions during firm } i \text { 's conference call in quarter } t \text {. }\end{array}$ \\
\hline \#Answers & $\begin{array}{l}\text { Number of answers to analyst } a \text { 's questions during firm } i \text { 's conference call } \\
\text { in quarter } t \text {, measured as the sum of speaker changes within the manage- } \\
\text { ment's answer to analyst } a \text { 's questions during firm } i \text { 's conference call in } \\
\text { quarter } t \text {. }\end{array}$ \\
\hline Abn\#Answers & $\begin{array}{l}\text { Abnormal number of answers in management's answer to analyst } a \text { 's ques- } \\
\text { tion during firm } i \text { 's conference call in quarter } t \text {, calculated as \#Answersa,i,t } \\
\text { less the smallest \#Answers } a, i, t \text { for any analyst participating in firm } i \text { 's con- } \\
\text { ference call in quarter } t \text {, with this difference scaled by the range in } \\
\text { \#Answers } a_{a, i, t} \text { for all answers to analysts' questions during firm } i \text { 's confer- } \\
\text { ence call in quarter } t \text {. }\end{array}$ \\
\hline Tone $Q$ & $\begin{array}{l}\text { Tone of analyst } a \text { 's question during firm } i \text { 's conference call in quarter } t \text {, } \\
\text { calculated as the difference between positive and negative word counts of } \\
\text { all words contained in the word list of Loughran and McDonald (2011) } \\
\text { scaled by the number of words in analyst a's question during firm } i \text { 's con- } \\
\text { ference call in quarter } t \text {. }\end{array}$ \\
\hline
\end{tabular}




\begin{tabular}{|c|c|}
\hline AbnTone $Q$ & $\begin{array}{l}\text { Abnormal tone of analyst } a \text { 's question during firm } i \text { 's conference call in } \\
\text { quarter } t \text {, calculated as Tone } Q_{a, i, t} \text { less the smallest Tone } Q_{a, i, t} \text { for any analyst } \\
\text { participating in firm } i \text { 's conference call in quarter } t \text {, with this difference } \\
\text { scaled by the range in Tone } Q_{a, i, t} \text { for all analysts participating in firm } i \text { 's } \\
\text { conference call in quarter } t \text {. }\end{array}$ \\
\hline ToneA & $\begin{array}{l}\text { Tone of management's answer to analyst } a \text { 's question during firm } i \text { 's con- } \\
\text { ference call in quarter } t \text {, calculated as the difference between positive and } \\
\text { negative word counts of all words contained in the word list of Loughran } \\
\text { and McDonald (2011) scaled by the number of words in the managements } \\
\text { answer to analyst a's question during firm i's conference call in quarter } t \text {. }\end{array}$ \\
\hline \#Numbers & $\begin{array}{l}\text { References to percentage and currency numbers in analyst } a \text { 's question dur- } \\
\text { ing firm } i \text { 's conference call in quarter } t \text {, calculated as the count of all per- } \\
\text { centage and currency numbers in analyst a's question during firm } i \text { 's con- } \\
\text { ference call in quarter } t \text {. }\end{array}$ \\
\hline Abn\#Numbers & $\begin{array}{l}\text { Abnormal number of percentage and currency number references of analyst } \\
a \text { 's question during firm } i \text { 's conference call in quarter } t \text {, calculated as } \\
\# N u m b e r s_{a, i, t} \text { less the smallest \#Numbers } s_{a, i, t} \text { for any analyst participating in } \\
\text { firm } i \text { 's conference call in quarter } t \text {, with this difference scaled by the range } \\
\text { in \#Numbersa,i,t for all analysts participating in firm } i \text { 's conference call in } \\
\text { quarter } t \text {. }\end{array}$ \\
\hline LagPartic & $\begin{array}{l}\text { Indicator variable equal to } 1 \text { if analyst } a \text { asked a question in the conference } \\
\text { call of firm } i \text { in quarter } t-1,0 \text { otherwise. }\end{array}$ \\
\hline PosQuestion & $\begin{array}{l}\text { Natural logarithm of the position of analyst } a \text { 's question in the conference } \\
\text { call of firm } i \text { in quarter } t\end{array}$ \\
\hline \#Questions & $\begin{array}{l}\text { Natural logarithm of the number of analyst } a \text { 's questions during the confer- } \\
\text { ence call of firm } i \text { in quarter } t\end{array}$ \\
\hline \multicolumn{2}{|r|}{ Call variables } \\
\hline$A v g \operatorname{Info} Q$ & $\begin{array}{l}\text { Average information sharing of all analysts during firm } i \text { 's conference call } \\
\text { in quarter } t \text {, calculated as the average of Info } Q_{a, i, t} \text { of all analysts participat- } \\
\text { ing in firm } i \text { 's conference call in quarter } t \text {. }\end{array}$ \\
\hline AvgInfoA & $\begin{array}{l}\text { Average information sharing of the management in their answers to all an- } \\
\text { alysts' questions during firm } i \text { 's conference call in quarter } t \text {, calculated as } \\
\text { the average of Info } A_{a, i, t} \text { of all answers to analysts' questions during firm } i \text { 's } \\
\text { conference call in quarter } t \text {. }\end{array}$ \\
\hline ToneMP & $\begin{array}{l}\text { Tone of the management presentation in firm } i \text { 's conference call in quarter } \\
t \text {, calculated as the difference between positive and negative word counts } \\
\text { of all words contained in the word list of Loughran and McDonald (2011) } \\
\text { scaled by the number of words of the management presentation during firm } \\
i \text { 's conference call in quarter } t \text {. }\end{array}$ \\
\hline AvgTone $Q$ & $\begin{array}{l}\text { Average tone of all analysts during firm } i \text { 's conference call in quarter } t \text {, } \\
\text { calculated as the average of Tone } Q_{a, i, t} \text { of all analysts participating in firm } \\
i \text { 's conference call in quarter } t \text {. }\end{array}$ \\
\hline
\end{tabular}


Average tone of the managements' answers to all analysts' questions dur-

AvgToneA ing firm i's conference call in quarter $t$, calculated as the average of Tone $A_{a, i, t}$ of all answers to analysts' questions during firm $i$ 's conference call in quarter $t$.

\begin{tabular}{ll} 
Participants & $\begin{array}{l}\text { Natural logarithm of the number of analysts asking a question during the } \\
\text { conference call of firm } i \text { in quarter } t \text {. }\end{array}$ \\
\hline Competition & $\begin{array}{l}\text { Share of participating analysts that have also participated in the last con- } \\
\text { ference call. Measured as average of analysts' lagged participation } \\
(\text { LagPartica,i,t) in firm } i \text { 's conference call in quarter } t .\end{array}$ \\
\hline
\end{tabular}

\begin{tabular}{ll} 
Uncertainty $_{t}$ & $\begin{array}{l}\text { Standard deviation in EPS forecasts for firm } i \text { for quarter } t+1 \text { provided } \\
\text { before the conference call of firm } i \text { in quarter } t .\end{array}$ \\
\hline \multirow{2}{*}{ Uncertainty $_{t+1}$} & $\begin{array}{l}\text { Standard deviation in EPS forecasts for firm } i \text { for quarter } t+1 \text { provided } \\
\text { after the conference call of firm } i \text { in quarter } t .\end{array}$ \\
\hline
\end{tabular}

\begin{tabular}{|c|c|}
\hline \multicolumn{2}{|r|}{ Firm variables } \\
\hline Size & Natural logarithm of total assets in thousands of firm $i$ in quarter $t$. \\
\hline BTM & $\begin{array}{l}\text { Book value of equity divided by market value of equity of firm } i \text { in quar- } \\
\text { ter } t \text {. }\end{array}$ \\
\hline Leverage & $\begin{array}{l}\text { Leverage share of equity (long term debt }+ \text { short term liabilities)/common } \\
\text { equity of firm } i \text { in quarter } t \text {. }\end{array}$ \\
\hline Coverage & $\begin{array}{l}\text { Natural logarithm of the average number of forecasts provided for firm } i \\
\text { regarding earnings in quarter } t+1 \text { at the date of the conference call in quar- } \\
\text { ter } t \text {. }\end{array}$ \\
\hline Beat & $\begin{array}{l}\text { Indicator variable equal to } 1 \text { if actual earnings exceed consensus analysts' } \\
\text { earnings forecast (EPS }>\text { Actual), } 0 \text { otherwise. }\end{array}$ \\
\hline Surprise & $\begin{array}{l}\text { Difference between quarterly EPS and analyst consensus forecast of firm } i \\
\text { in quarter } t \text {. }\end{array}$ \\
\hline$\triangle R O A$ & Change in return on assets of firm $i$ between quarter $t$ and quarter $t-1$. \\
\hline Loss & $\begin{array}{l}\text { Indicator variable equal to } 1 \text { if firm } i \text { reports negative earnings in quarter } t \text {, } \\
0 \text { otherwise. }\end{array}$ \\
\hline$C A R[0,+1]$ & $\begin{array}{l}\text { Cumulative abnormal size-decile adjusted return for firm } i \text { during }[0,+1] \\
\text { trading window around the conference call date in quarter } t \text {. }\end{array}$ \\
\hline
\end{tabular}

Notes: This table lists the variables used in the empirical analysis and their description. Note that all continuous variables are winsorized at 1 and 99 percent level. 


\section{References}

Abraham, S., \& Bamber, M. (2017). The Q\&A: Under surveillance. Accounting, Organizations and Society, 58, 15-31.

Asquith, P., Mikhail, M. B., \& Au, A. S. (2005). Information content of equity analyst reports. Journal of Financial Economics, 75(2), 245-282.

Baginski, S. P., Hassell, J. M., \& Kimbrough, M. D. (2004). Why Do Managers Explain Their Earnings Forecasts? Journal of Accounting Research, 42(1), 1-29.

Bloomfield, R., \& Hales, J. (2009). An Experimental Investigation of the Positive and Negative Effects of Mutual Observation. The Accounting Review, 84(2), 331-354.

Bowen, R. M., Davis, A. K., \& Matsumoto, D. (2002). Do Conference Calls Affect Analysts' Forecasts? The Accounting Review, 77(2), 285-316.

Bowers, A. H., Greve, H. R., Mitsuhashi, H., \& Baum, J. A. C. (2014). Competitive Parity, Status Disparity, and Mutual Forbearance: Securities Analysts' Competition for Investor Attention. Academy of Management Journal, 57(1), 38-62.

Brown, L. D., Call, A. C., Clement, M. B., \& Sharp, N. Y. (2015). Inside the "Black Box" of Sell-Side Financial Analysts. Journal of Accounting Research, 53(1), 1-47.

Brown, S., \& Hillegeist, S. A. (2007). How disclosure quality affects the level of information asymmetry. Review of Accounting Studies, 12(2-3), 443-477.

Brown, S., Hillegeist, S. A., \& Lo, K. (2009). The effect of earnings surprises on information asymmetry. Journal of Accounting and Economics, 47(3), 208-225.

Brown, S., \& Tucker, J. W. U. (2011). Large-Sample Evidence on Firms' Year-over-Year MD\&A Modifications. Journal of Accounting Research, 49(2), 309-346.

Bushee, B. J., Core, J. E., Guay, W., \& Hamm, S. J. (2010). The Role of the Business Press as an Information Intermediary. Journal of Accounting Research, 48(1), 1-19. 
Call, A. C., Flam, R., Lee, J., \& Sharp, N. Y. (2020). Analysts' and Managers' Use of Humor on Public Earnings Conference Calls. SSRN Electronic Journal. Advance online publication.

Chen, Q., Francis, J., \& Jiang, W. (2005). Investor learning about analyst predictive ability. Journal of Accounting and Economics, 39(1), 3-24.

Chen, S., Hollander, S., \& Law, K. (2016). In Search of Interaction. SSRN Electronic Journal. Advance online publication.

Christensen and Associates. (1992). Survey on Teleconferencing. Stamford, Conn.: Christensen and Associates.

Cicon, J. (2017). Say it again Sam: the information content of corporate conference calls. Review of Quantitative Finance and Accounting, 48(1), 57-81.

Diamond, D. W. (1985). Optimal Release of Information By Firms. The Journal of Finance, 40(4), 1071-1094.

Diether, K. B., Malloy, C. J., \& Scherbina, A. (2002). Differences of Opinion and the Cross Section of Stock Returns. The Journal of Finance, 57(5), 2113-2141.

Emery, D. R., \& Li, X. (2009). Are the Wall Street Analyst Rankings Popularity Contests? Journal of Financial and Quantitative Analysis, 44(2), 411-437.

Ertimur, Y., Sunder, J., \& Sunder, S. V. (2007). Measure for Measure: The Relation between Forecast Accuracy and Recommendation Profitability of Analysts. Journal of Accounting Research, 45(3), 567-606.

Feichter, C., Moers, F., \& Timmermans, O. (2020). The Effect of Peer Group Overlap in Executives' RPE Contracts on Competitive Aggressiveness. SSRN Electronic Journal. Advance online publication.

Glosten, L. R., \& Harris, L. E. (1988). Estimating the components of the bid/ask spread. Journal of Financial Economics, 21(1), 123-142. 
Gow, I. D., Larcker, D. F., \& Zakolyukina, A. A. (2021). Non-answers during Conference Calls. Journal of Accounting Research. Advance online publication.

Groysberg, B., Healy, P. M., \& Maber, D. A. (2011). What Drives Sell-Side Analyst Compensation at High-Status Investment Banks? Journal of Accounting Research, 49(4), 9691000.

Haag, J., Hofmann, C., Klausing, S., \& Schwaiger, N. (2021). Strike the right tone: Financial analysts' strategic use of tone in earnings conference calls.

Healy, P. M., \& Palepu, K. G. (2001). Information asymmetry, corporate disclosure, and the capital markets: A review of the empirical disclosure literature. Journal of Accounting and Economics, 31(1-3), 405-440.

Hong, H., \& Kacperczyk, M. (2010). Competition and Bias. The Quarterly Journal of Economics, 125(4), 1683-1725.

Hong, H., \& Kubik, J. D. (2003). Analyzing the Analysts: Career Concerns and Biased Earnings Forecasts. The Journal of Finance, 58(1), 313-351.

Hope, O.-K., \& Wang, J. (2018). Management deception, big-bath accounting, and information asymmetry: Evidence from linguistic analysis. Accounting, Organizations and Society, 70, 33-51.

Huang, A. H., Lehavy, R., Zang, A. Y., \& Zheng, R. (2018). Analyst Information Discovery and Interpretation Roles: A Topic Modeling Approach. Management Science, 64(6), 28332855.

Hugon, A., Kumar, A., \& Lin, A.-P. (2016). Analysts, Macroeconomic News, and the Benefit of Active In-House Economists. The Accounting Review, 91(2), 513-534.

Hutton, A. P., Lee, L. F., \& Shu, S. Z. (2012). Do Managers Always Know Better? The Relative Accuracy of Management and Analyst Forecasts. Journal of Accounting Research, $50(5), 1217-1244$. 
Kothari, S. P., Shu, S., \& Wysocki, P. D. (2009). Do Managers Withhold Bad News? Journal of Accounting Research, 47(1), 241-276.

Kumar, A., Rantala, V., \& Xu, R. (2020). Social Learning and Analyst Behavior. SSRN Electronic Journal. Advance online publication.

Lee, J. (2016). Can Investors Detect Managers' Lack of Spontaneity? Adherence to Predetermined Scripts during Earnings Conference Calls. The Accounting Review, 91(1), 229-250.

Leuz, C. (2003). IAS Versus U.S. GAAP: Information Asymmetry-Based Evidence from Germany's New Market. Journal of Accounting Research, 41(3), 445-472.

Ljungqvist, A., Malloy, C., \& Marston, F. (2009). Rewriting History. The Journal of Finance, 64(4), 1935-1960.

Loh, R. K., \& Mian, G. M. (2006). Do accurate earnings forecasts facilitate superior investment recommendations? Journal of Financial Economics, 80(2), 455-483.

Loh, R. K., \& Stulz, R. M. (2011). When Are Analyst Recommendation Changes Influential? Review of Financial Studies, 24(2), 593-627.

Loughran, T., \& McDonald, B. (2011). When Is a Liability Not a Liability? Textual Analysis, Dictionaries, and 10-Ks. The Journal of Finance, 66(1), 35-65.

Manela, A., \& Moreira, A. (2017). News implied volatility and disaster concerns. Journal of Financial Economics, 123(1), 137-162.

Martin, M., \& Timmermans, O. (2021). Incentive Contracts and Corporate Disclosure: Evidence from Relative Performance Evaluation. SSRN Electronic Journal. Advance online publication.

Matsumoto, D., Pronk, M., \& Roelofsen, E. (2011). What Makes Conference Calls Useful? The Information Content of Managers' Presentations and Analysts' Discussion Sessions. The Accounting Review, 86(4), 1383-1414. 
Mayew, W. J. (2008). Evidence of Management Discrimination Among Analysts during Earnings Conference Calls. Journal of Accounting Research, 46(3), 627-659.

Mayew, W. J., Sethuraman, M., \& Venkatachalam, M. (2020). Individual Analysts' Stock Recommendations, Earnings Forecasts, and the Informativeness of Conference Call Question and Answer Sessions. The Accounting Review, 95(6), 331-337.

Mayew, W. J., Sharp, N. Y., \& Venkatachalam, M. (2013). Using earnings conference calls to identify analysts with superior private information. Review of Accounting Studies, 18(2), $386-413$.

Mikhail, M. B., Walther, B. R., \& Willis, R. H. (1999). Does Forecast Accuracy Matter to Security Analysts? The Accounting Review, 74(2), 185-200.

Milgrom, P. R., \& Roberts, J. (1992). Economics, organization and management. Prentice Hall.

Minson, J. A., VanEpps, E. M., Yip, J. A., \& Schweitzer, M. E. (2018). Eliciting the truth, the whole truth, and nothing but the truth: The effect of question phrasing on deception. Organizational Behavior and Human Decision Processes, 147, 76-93.

Salton, G., \& Buckley, C. (1988). Term-weighting approaches in automatic text retrieval. Information Processing \& Management, 24(5), 513-523.

Stickel, S. E. (1992). Reputation and Performance Among Security Analysts. The Journal of Finance, 47(5), 1811-1836.

Timmermans, O. (2020). What Are the Risk-Taking Properties of Incentive Plans Based on Relative Performance? SSRN Electronic Journal. Advance online publication.

Verrecchia, R. E. (1982). Information Acquisition in a Noisy Rational Expectations Economy. Econometrica, 50(6), 1415-1430. 
Table 1: Sample

Sample

Observations

Nr. of total conference call transcripts

156,468

- Conference calls without Q\&A session

5,116

- Transcripts with missing/incorrect firm/time identifier

8,646

- Firm-quarters with missing fundamentals (Compustat)

Nr. of conference call transcripts

109,509

Thereof: Nr. of unique firms

4,448

Total nr of analysts' speech portion

$\mathbf{7 9 9 , 1 0 5}$

- No name match with IBES Recommendation

367,635

- No match with IBES Detail/missing abnormal measures

107,046

Number of matched of analysts' speech portion

260,589

Thereof: Nr. of conference call transcripts

Thereof: Nr. of unique firms

Thereof: Nr. of unique analysts

Thereof: Nr. of unique brokerage houses

Avg. Nr. of matched analysts' speech portions per conference call

Notes: Table 1 describes the sample selection process and presents the final sample of the analysis. The sample includes all US-conference calls held between from 01/01/2008 to 09/11/2020. All transcripts are downloaded from Thompson Reuters EIKON. 
Table 2: Summary statistics

\begin{tabular}{|c|c|c|c|c|c|c|c|c|}
\hline Variables & $N$ & Mean & $S D$ & $1^{s t}$ & $25^{\text {th }}$ & Median & $75^{\text {th }}$ & $99^{\text {th }}$ \\
\hline \multicolumn{9}{|c|}{ Panel A: Analyst variables } \\
\hline Info $Q$ & 260,589 & 0.84 & 0.07 & 0.64 & 0.79 & 0.84 & 0.89 & 0.97 \\
\hline AbnInfoQ & 260,589 & 0.52 & 0.33 & 0.00 & 0.25 & 0.54 & 0.80 & 1.00 \\
\hline InfoA & 260,589 & 0.77 & 0.09 & 0.53 & 0.71 & 0.77 & 0.83 & 0.97 \\
\hline AbnInfoA & 260,589 & 0.50 & 0.33 & 0.00 & 0.22 & 0.50 & 0.77 & 1.00 \\
\hline$F E_{t}$ & 260,589 & 0.18 & 0.31 & 0.00 & 0.03 & 0.08 & 0.18 & 2.17 \\
\hline$A b n F A_{t}$ & 260,589 & 0.56 & 0.34 & 0.00 & 0.29 & 0.60 & 0.86 & 1.00 \\
\hline$F E_{t+1}$ & 260,589 & 0.14 & 0.25 & 0.00 & 0.02 & 0.06 & 0.14 & 1.73 \\
\hline$A b n F A_{t+1}$ & 260,589 & 0.56 & 0.34 & 0.00 & 0.29 & 0.60 & 0.88 & 1.00 \\
\hline$\triangle F A$ & 260,589 & 0.03 & 0.13 & -0.32 & -0.02 & 0.01 & 0.06 & 0.76 \\
\hline $\operatorname{Rec}$ & 260,589 & 3.80 & 0.86 & 2.00 & 3.00 & 4.00 & 4.00 & 5.00 \\
\hline AbnRec & 260,589 & 0.51 & 0.38 & 0.00 & 0.00 & 0.50 & 1.00 & 1.00 \\
\hline \#Forc & 260,589 & 157.80 & 80.65 & 21.00 & 103.00 & 144.00 & 197.00 & 442.00 \\
\hline Abn\#Forc & 260,589 & 0.48 & 0.33 & 0.00 & 0.22 & 0.45 & 0.74 & 1.00 \\
\hline \#Cотр & 260,589 & 16.95 & 6.46 & 3.00 & 13.00 & 16.00 & 21.00 & 36.00 \\
\hline Abn\#Сотp & 260,589 & 0.47 & 0.32 & 0.00 & 0.20 & 0.45 & 0.71 & 1.00 \\
\hline \#Ind & 260,589 & 3.99 & 2.31 & 1.00 & 2.00 & 4.00 & 5.00 & 11.00 \\
\hline Abn\#Ind & 260,589 & 0.41 & 0.35 & 0.00 & 0.00 & 0.33 & 0.67 & 1.00 \\
\hline FirmExp & 260,589 & 5.03 & 4.43 & 0.31 & 1.67 & 3.65 & 7.08 & 20.96 \\
\hline AbnFirmExp & 260,589 & 0.47 & 0.37 & 0.00 & 0.12 & 0.40 & 0.85 & 1.00 \\
\hline GenExp & 260,589 & 12.16 & 8.08 & 0.64 & 5.70 & 10.55 & 17.22 & 32.81 \\
\hline AbnGenExp & 260,589 & 0.43 & 0.34 & 0.00 & 0.13 & 0.37 & 0.70 & 1.00 \\
\hline RecHoriz & 260,589 & 1.37 & 1.44 & 0.02 & 0.36 & 0.88 & 1.86 & 7.12 \\
\hline AbnRecHoriz & 260,589 & 0.34 & 0.34 & 0.00 & 0.05 & 0.22 & 0.56 & 1.00 \\
\hline SizeBrok & 260,589 & 57.99 & 35.47 & 2.00 & 25.00 & 58.00 & 90.00 & 126.00 \\
\hline AbnSizeBrok & 260,589 & 0.49 & 0.35 & 0.00 & 0.16 & 0.50 & 0.81 & 1.00 \\
\hline$\#$ \#ordsQ & 260,589 & 163.35 & 81.99 & 31.00 & 104.00 & 149.00 & 207.00 & 437.00 \\
\hline Abn\#Words $Q$ & 260,589 & 0.46 & 0.33 & 0.00 & 0.19 & 0.42 & 0.73 & 1.00 \\
\hline \#WordsA & 260,589 & 395.12 & 224.84 & 37.00 & 231.00 & 355.00 & 514.00 & $1,149.00$ \\
\hline Abn\#WordsA & 260,589 & 0.47 & 0.33 & 0.00 & 0.19 & 0.43 & 0.74 & 1.00 \\
\hline \#Answers & 260,589 & 4.05 & 2.56 & 1.00 & 2.00 & 3.00 & 5.00 & 14.00 \\
\hline Abn\#Answers & 260,589 & 0.42 & 0.35 & 0.00 & 0.11 & 0.33 & 0.67 & 1.00 \\
\hline Tone $Q$ & 260,589 & 0.00 & 0.01 & -0.03 & 0.00 & 0.00 & 0.01 & 0.04 \\
\hline AbnTone $Q$ & 260,589 & 0.48 & 0.33 & 0.00 & 0.22 & 0.47 & 0.74 & 1.00 \\
\hline ToneA & 260,589 & 0.01 & 0.01 & -0.02 & 0.00 & 0.01 & 0.01 & 0.04 \\
\hline \#Numbers & 260,589 & 1.95 & 3.51 & 0.00 & 0.00 & 0.00 & 2.00 & 18.00 \\
\hline Abn\#Numbers & 260,589 & 0.23 & 0.36 & 0.00 & 0.00 & 0.00 & 0.38 & 1.00 \\
\hline LagPartic & 260,589 & 0.61 & 0.49 & 0.00 & 0.00 & 1.00 & 1.00 & 1.00 \\
\hline PosQuestion & 260,589 & 1.41 & 0.77 & 0.00 & 0.69 & 1.61 & 1.95 & 2.77 \\
\hline \#Questions & 260,589 & 1.14 & 0.59 & 0.00 & 0.69 & 1.10 & 1.61 & 2.40 \\
\hline
\end{tabular}


Table 2: Summary statistics (continued)

Panel B: Call variables

\begin{tabular}{|c|c|c|c|c|c|c|c|c|}
\hline AvgInfo $Q$ & 70,089 & 0.84 & 0.04 & 0.74 & 0.81 & 0.84 & 0.86 & 0.92 \\
\hline$A v g \operatorname{Info} A$ & 70,089 & 0.77 & 0.06 & 0.62 & 0.73 & 0.77 & 0.81 & 0.89 \\
\hline ToneMP & 70,089 & 0.01 & 0.01 & -0.01 & 0.01 & 0.01 & 0.02 & 0.03 \\
\hline AvgTone $Q$ & 70,089 & 0.00 & 0.01 & -0.01 & 0.00 & 0.00 & 0.01 & 0.02 \\
\hline AvgToneA & 70,089 & 0.01 & 0.01 & -0.01 & 0.00 & 0.01 & 0.01 & 0.02 \\
\hline Participants & 70,089 & 2.05 & 0.44 & 1.10 & 1.79 & 2.08 & 2.40 & 2.94 \\
\hline Competition & 70,089 & 0.61 & 0.34 & 0.00 & 0.40 & 0.67 & 1.00 & 1.00 \\
\hline Uncertainty $_{t}$ & 70,089 & 0.08 & 0.14 & 0.01 & 0.02 & 0.04 & 0.08 & 0.99 \\
\hline Uncertainty $_{t+1}$ & 70,089 & 0.07 & 0.12 & 0.00 & 0.02 & 0.03 & 0.07 & 0.85 \\
\hline \multicolumn{9}{|c|}{ Panel C: Firm variables } \\
\hline Size & 70,089 & 7.89 & 1.78 & 4.24 & 6.64 & 7.81 & 9.04 & 12.46 \\
\hline BTM & 70,089 & 0.50 & 0.42 & -0.33 & 0.22 & 0.41 & 0.68 & 2.05 \\
\hline Leverage & 70,089 & 0.59 & 0.27 & 0.09 & 0.41 & 0.58 & 0.76 & 1.41 \\
\hline Coverage & 70,089 & 2.37 & 0.55 & 1.10 & 1.95 & 2.40 & 2.77 & 3.43 \\
\hline Beat & 70,089 & 0.63 & 0.48 & 0.00 & 0.00 & 1.00 & 1.00 & 1.00 \\
\hline Surprise & 70,089 & 0.03 & 0.18 & -0.76 & -0.01 & 0.02 & 0.07 & 0.77 \\
\hline$\triangle R O A$ & 70,089 & 0.01 & 0.04 & -0.15 & 0.01 & 0.02 & 0.03 & 0.11 \\
\hline Loss & 70,089 & 0.24 & 0.42 & 0.00 & 0.00 & 0.00 & 0.00 & 1.00 \\
\hline$C A R[0,+1]$ & 70,089 & 0.00 & 0.08 & -0.25 & -0.04 & 0.00 & 0.04 & 0.23 \\
\hline
\end{tabular}

Notes: Table 2 lists the variables used in the empirical analysis and the corresponding distribution parameters. Note that all variables are winsorized at the 1 and 99 percent level. For an overview on the variables please see Appendix 1. 
Table 3: Pearson-Spearman correlation matrix

\begin{tabular}{|c|c|c|c|c|c|c|c|c|c|c|c|c|c|c|c|c|c|}
\hline \multicolumn{2}{|c|}{ Variables } & \multirow{2}{*}{$\begin{array}{r}(1) \\
\mathbf{1 . 0 0}\end{array}$} & \multirow{2}{*}{$\begin{array}{r}(2) \\
0.38\end{array}$} & \multirow{2}{*}{$\begin{array}{r}\text { (3) } \\
\mathbf{- 0 . 0 1}\end{array}$} & \multirow{2}{*}{$\begin{array}{r}(4) \\
\mathbf{- 0 . 0 1}\end{array}$} & \multirow{2}{*}{$\begin{array}{r}(5) \\
0.00\end{array}$} & \multirow{2}{*}{$\begin{array}{r}(6) \\
0.01\end{array}$} & \multirow{2}{*}{$\begin{array}{r}(7) \\
\mathbf{- 0 . 0 1}\end{array}$} & \multirow{2}{*}{$\begin{array}{r}(8) \\
0.01\end{array}$} & \multirow{2}{*}{$\begin{array}{r}(9) \\
\mathbf{0 . 0 1}\end{array}$} & \multirow{2}{*}{$\begin{array}{r}(10) \\
\mathbf{- 0 . 0 2}\end{array}$} & \multirow{2}{*}{$\frac{(11)}{\mathbf{0 . 0 1}}$} & \multirow{2}{*}{$\begin{array}{r}(12) \\
\mathbf{- 0 . 0 1}\end{array}$} & \multirow{2}{*}{$\begin{array}{r}(13) \\
\mathbf{- 0 . 0 3}\end{array}$} & \multirow{2}{*}{$\begin{array}{r}(14) \\
\mathbf{- 0 . 0 6}\end{array}$} & \multirow{2}{*}{$\begin{array}{r}(15) \\
\mathbf{- 0 . 0 2}\end{array}$} & \multirow{2}{*}{$\begin{array}{r}(16) \\
\mathbf{- 0 . 2 4}\end{array}$} \\
\hline (1) & AbnInfo $Q$ & & & & & & & & & & & & & & & & \\
\hline (2) & AbnInfoA & 0.38 & 1.00 & 0.00 & 0.00 & 0.00 & -0.01 & -0.04 & -0.03 & -0.01 & -0.02 & 0.00 & -0.03 & -0.05 & -0.06 & -0.02 & -0.14 \\
\hline (3) & $A b n F A_{t}$ & -0.01 & 0.00 & 1.00 & 0.22 & -0.39 & 0.00 & 0.01 & -0.01 & 0.00 & 0.00 & 0.00 & 0.00 & 0.00 & 0.01 & 0.00 & 0.00 \\
\hline (4) & $A b n F A_{t+1}$ & -0.01 & 0.00 & 0.24 & 1.00 & 0.26 & -0.01 & -0.01 & -0.02 & -0.02 & 0.01 & 0.00 & 0.00 & -0.01 & 0.00 & -0.01 & 0.01 \\
\hline (5) & $\Delta F A$ & 0.00 & 0.00 & -0.27 & 0.18 & 1.00 & 0.00 & -0.01 & 0.00 & 0.01 & -0.01 & 0.00 & 0.00 & -0.02 & -0.01 & 0.01 & 0.01 \\
\hline (6) & AbnRec & 0.01 & -0.01 & 0.00 & -0.01 & 0.01 & 1.00 & -0.07 & -0.05 & 0.01 & 0.02 & 0.01 & 0.11 & -0.09 & 0.05 & 0.01 & -0.02 \\
\hline (7) & Abn\#Forc & -0.01 & -0.04 & 0.00 & -0.01 & -0.01 & -0.07 & 1.00 & 0.76 & & & & & 0.23 & & -0.01 & 0.01 \\
\hline (8) & Abn\#Comp & 0.01 & -0.03 & -0.01 & -0.02 & 0.00 & -0.05 & 0.76 & 1.00 & 0.42 & 0.17 & 0.24 & 0.09 & 0.16 & 0.01 & -0.01 & 0.00 \\
\hline (9) & Abn\#Ind & 0.01 & -0.01 & -0.01 & -0.02 & 0.00 & 0.01 & 0.30 & 0.42 & 1.00 & 0.07 & 0.13 & 0.06 & -0.01 & 0.00 & 0.00 & 0.00 \\
\hline (10) & AbnFirmExp & -0.02 & -0.02 & 0.00 & 0.01 & 0.00 & $\mathbf{0 . 0 3}$ & 0.14 & 0.16 & 0.07 & 1.00 & 0.41 & 0.29 & -0.01 & 0.10 & -0.02 & 0.03 \\
\hline (11) & AbnGenExp & 0.01 & 0.00 & -0.01 & -0.01 & 0.00 & 0.01 & 0.16 & 0.21 & 0.12 & 0.39 & 1.00 & 0.12 & -0.06 & 0.02 & -0.02 & 0.02 \\
\hline (12) & AbnRecHoriz & -0.02 & -0.03 & -0.01 & -0.01 & 0.00 & 0.11 & 0.08 & 0.09 & 0.06 & 0.29 & 0.11 & 1.00 & 0.01 & 0.18 & 0.00 & 0.01 \\
\hline (13) & AbnSizeBrok & -0.03 & -0.05 & 0.00 & -0.01 & -0.01 & -0.09 & 0.23 & 0.16 & -0.01 & -0.01 & -0.06 & 0.00 & 1.00 & 0.03 & -0.01 & 0.00 \\
\hline (14) & LagPartic & -0.06 & -0.06 & 0.01 & 0.01 & -0.01 & 0.05 & 0.03 & 0.01 & 0.00 & 0.08 & 0.01 & 0.14 & 0.03 & 1.00 & 0.00 & 0.03 \\
\hline (15) & AbnTone $Q$ & -0.02 & -0.02 & 0.00 & -0.01 & 0.01 & 0.01 & -0.01 & -0.01 & 0.00 & -0.01 & -0.02 & 0.00 & -0.01 & 0.00 & 1.00 & -0.04 \\
\hline (16) & Abn\#Numbers & -0.24 & -0.14 & 0.00 & 0.00 & -0.01 & -0.01 & 0.01 & 0.00 & 0.00 & 0.03 & 0.02 & 0.02 & 0.00 & 0.04 & -0.04 & 1.00 \\
\hline
\end{tabular}

Notes: Table 3 displays the Pearson (bottom left) and Spearman (top right) correlation coefficients for the variables used in the empirical analysis. Significant coefficients at the $10 \%$ level are bolded. AbnInfo $\boldsymbol{O}$ captures an analyst's information sharing in the question. $\boldsymbol{A b n I n f o A}$ captures manager's information sharing in the answer. AbnFAt captures an analyst's relative forecast accuracy before the conference call in quarter $t$, regarding earnings in quarter $t+1$. AbnFA $\boldsymbol{A}_{t+1}$ captures an analyst's relative forecast accuracy after the conference call in quarter $t$, regarding earnings in $t+1 . \Delta \boldsymbol{F A}$ captures an analyst's improvement in forecast accuracy around the conference call, regarding earnings in $t+1$. AbnRec measures an analyst's stock recommendation. Abn\#Forc measures an analyst's number of quarterly EPS forecasts. Abn\#Comp measures an analyst's number of covered firms. Abn\#Ind measures the coverage of an analyst within the two-digit SIC industry. AbnFirmExp measures an analyst's firm experience. AbnGenExp measures an analyst's general experience. AbnRecHoriz measures an analyst's stock recommendation horizon. AbnSizeBrok measures an analyst's size of the brokerage house, identified by the number of employed analysts. LagPartic is an indicator variable equal to 1 if the analyst participated in the conference call in $t-1$. AbnTone $Q$ measures an analyst's tone in the question. Abn\#Numbers measures an analyst's share of numbers in the question. For a detailed overview on the variables please see Appendix 1. 
Table 4: Consequences of information sharing

\begin{tabular}{|c|c|}
\hline Variables & $\begin{array}{c}(1) \\
A b n F A_{t+1}\end{array}$ \\
\hline & Coeff. \\
\hline AbnInfoQ & $\begin{array}{c}-0.006 * * * \\
(-2.59)\end{array}$ \\
\hline$A b n F A_{t}$ & $\begin{array}{c}0.237 * * * \\
(73.60)\end{array}$ \\
\hline AbnRec & $\begin{array}{c}-0.009 * * * \\
(-3.81)\end{array}$ \\
\hline Abn\#Forc & $\begin{array}{c}0.007 * \\
(1.73)\end{array}$ \\
\hline Abn\#Comp & $\begin{array}{c}-0.007 \\
(-1.53)\end{array}$ \\
\hline Abn\#Ind & $\begin{array}{c}-0.005 \\
(-1.50)\end{array}$ \\
\hline AbnFirmExp & $\begin{array}{c}0.006 * * \\
(2.28)\end{array}$ \\
\hline AbnGenExp & $\begin{array}{c}-0.002 \\
(-0.53)\end{array}$ \\
\hline AbnRecHoriz & $\begin{array}{c}-0.012 * * * \\
(-3.84)\end{array}$ \\
\hline AbnSizeBrok & $\begin{array}{c}0.002 \\
(0.94)\end{array}$ \\
\hline LagPartic & $\begin{array}{c}0.004 * * * \\
(2.76)\end{array}$ \\
\hline PosQuestion & $\begin{array}{c}-0.002 * * \\
(-2.35)\end{array}$ \\
\hline Participants & $\begin{array}{c}0.003 \\
(1.01)\end{array}$ \\
\hline Size & $\begin{array}{c}0.005 * * \\
(2.09)\end{array}$ \\
\hline BTM & $\begin{array}{c}-0.002 \\
(-0.54)\end{array}$ \\
\hline Leverage & $\begin{array}{c}-0.004 \\
(-0.65)\end{array}$ \\
\hline Coverage & $\begin{array}{c}0.021 * * * \\
\quad(4.85)\end{array}$ \\
\hline Beat & $\begin{array}{c}0.000 \\
(0.13)\end{array}$ \\
\hline Surprise & $\begin{array}{c}-0.015 * * * \\
(-2.96)\end{array}$ \\
\hline$\triangle R O A$ & $\begin{array}{c}-0.074 * \\
(-1.90)\end{array}$ \\
\hline Loss & $\begin{array}{c}-0.001 \\
(-0.45) \\
\end{array}$ \\
\hline $\mathrm{N}$ & 260,589 \\
\hline $\mathrm{R}^{2}$ & 0.089 \\
\hline Firm FE & YES \\
\hline Year FE & YES \\
\hline Quarter FE & YES \\
\hline Cluster & ANALYST \\
\hline
\end{tabular}

Notes: Table 4 displays the relation between information sharing by analysts and their next quarter relative forecast accu-

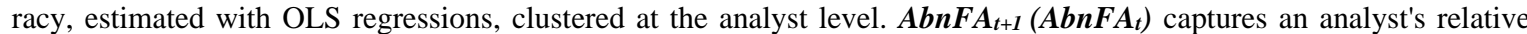
information endowment measured as analyst's relative forecast accuracy after (before) the conference call in quarter $t+1$ $(t)$, regarding earnings in quarter $t+1$. AbnInfo $Q$ captures analyst's information sharing in the question. For a detailed overview on the variables please see Appendix 1. The models are estimated with controls for analysts' characteristics and the firm's information environment, firm, year and quarter fixed effects. $*, * *, * *$ indicate two-tailed significance at the 10 percent, 5 percent, and 1 percent levels. t-values are reported in parentheses. 
Table 5: Determinants of information sharing

\begin{tabular}{|c|c|c|c|c|}
\hline Variables & $\stackrel{(1)}{\text { AbnInfo } Q}$ & $\begin{array}{c}(2) \\
\text { AbnInfo } Q\end{array}$ & $\begin{array}{c}(3) \\
\text { AbnInfo } Q\end{array}$ & $\begin{array}{c}(4) \\
A b n \operatorname{Info} Q\end{array}$ \\
\hline & Coeff. & Coeff. & Coeff. & Coeff. \\
\hline$A b n F A_{t}$ & $\begin{array}{c}-0.005 * * \\
(-2.33)\end{array}$ & & & $\begin{array}{c}-0.004 * * \\
(-2.31)\end{array}$ \\
\hline AbnFirmExp & & $\begin{array}{c}-0.017 * * * \\
(-4.57)\end{array}$ & & $\begin{array}{c}-0.015 * * * \\
(-4.02)\end{array}$ \\
\hline LagPartic & & & $\begin{array}{c}-0.030 * * * \\
(-19.24)\end{array}$ & $\begin{array}{c}-0.029 * * * \\
(-19.00)\end{array}$ \\
\hline AbnRec & $\begin{array}{c}0.010 * * * \\
(3.09)\end{array}$ & $\begin{array}{c}0.010 * * * \\
(3.10)\end{array}$ & $\begin{array}{c}0.011 * * * \\
(3.48)\end{array}$ & $\begin{array}{c}0.011 * * * \\
(3.49)\end{array}$ \\
\hline Abn\#Forc & $\begin{array}{c}-0.030 * * * \\
(-3.57)\end{array}$ & $\begin{array}{c}-0.029 * * * \\
(-3.52)\end{array}$ & $\begin{array}{c}-0.027 * * * \\
(-3.28)\end{array}$ & $\begin{array}{c}-0.026 * * * \\
(-3.21)\end{array}$ \\
\hline Abn\#Comp & $\begin{array}{c}0.035 * * * \\
(4.22)\end{array}$ & $\begin{array}{c}0.036 * * * \\
(4.34)\end{array}$ & $\begin{array}{c}0.032 * * * \\
(3.90)\end{array}$ & $\begin{array}{c}0.033 * * * \\
\quad(4.00)\end{array}$ \\
\hline Abn\#Ind & $\begin{array}{l}0.015 * * * \\
\quad(3.00)\end{array}$ & $\begin{array}{l}0.015 * * * \\
(2.93)\end{array}$ & $\begin{array}{c}0.015 * * * \\
(3.04)\end{array}$ & $\begin{array}{l}0.015 * * * \\
(2.97)\end{array}$ \\
\hline AbnGenExp & $\begin{array}{c}0.010 * \\
(1.66)\end{array}$ & $\begin{array}{l}0.017 * * * \\
(2.67)\end{array}$ & $\begin{array}{l}0.010 \\
(1.63)\end{array}$ & $\begin{array}{c}0.016^{* * *} \\
(2.51)\end{array}$ \\
\hline AbnRecHoriz & $\begin{array}{c}-0.016 * * * \\
(-2.70)\end{array}$ & $\begin{array}{c}-0.017 * * * \\
(-2.74)\end{array}$ & $\begin{array}{c}-0.016 * * * \\
(-2.59)\end{array}$ & $\begin{array}{c}-0.016 * * * \\
(-2.64)\end{array}$ \\
\hline AbnSizeBrok & $\begin{array}{c}-0.000 \\
(-0.13)\end{array}$ & $\begin{array}{c}0.004 \\
(1.09)\end{array}$ & $\begin{array}{c}0.005 \\
(1.63)\end{array}$ & $\begin{array}{c}0.009 * * * \\
(2.62)\end{array}$ \\
\hline PosQuestion & $\begin{array}{c}0.066 * * * \\
(38.14)\end{array}$ & $\begin{array}{c}0.066 * * * \\
(37.87)\end{array}$ & $\begin{array}{c}0.064 * * * \\
(37.24)\end{array}$ & $\begin{array}{c}0.064 * * * \\
(37.01)\end{array}$ \\
\hline Participants & $\begin{array}{c}-0.024 * * * \\
(-6.80)\end{array}$ & $\begin{array}{c}-0.024 * * * \\
(-6.87)\end{array}$ & $\begin{array}{c}-0.025 * * * \\
(-7.31)\end{array}$ & $\begin{array}{c}-0.025 * * * \\
(-7.36)\end{array}$ \\
\hline Size & $\begin{array}{l}0.002 \\
(0.56)\end{array}$ & $\begin{array}{c}0.002 \\
(0.55)\end{array}$ & $\begin{array}{c}0.002 \\
(0.64)\end{array}$ & $\begin{array}{c}0.002 \\
(0.64)\end{array}$ \\
\hline$B T M$ & $\begin{array}{c}0.001 \\
(0.40)\end{array}$ & $\begin{array}{c}0.001 \\
(0.41)\end{array}$ & $\begin{array}{c}0.001 \\
(0.28)\end{array}$ & $\begin{array}{c}0.001 \\
(0.29)\end{array}$ \\
\hline Leverage & $\begin{array}{l}0.000 \\
(0.05)\end{array}$ & $\begin{array}{c}0.000 \\
(0.07)\end{array}$ & $\begin{array}{c}-0.000 \\
(-0.07)\end{array}$ & $\begin{array}{c}-0.000 \\
(-0.06)\end{array}$ \\
\hline Coverage & $\begin{array}{c}0.005 \\
(1.09)\end{array}$ & $\begin{array}{c}0.004 \\
(0.99)\end{array}$ & $\begin{array}{c}0.007 * \\
(1.67)\end{array}$ & $\begin{array}{c}0.007 \\
(1.62)\end{array}$ \\
\hline Beat & $\begin{array}{c}-0.001 \\
(-0.50)\end{array}$ & $\begin{array}{c}-0.001 \\
(-0.47)\end{array}$ & $\begin{array}{c}-0.001 \\
(-0.54)\end{array}$ & $\begin{array}{c}-0.001 \\
(-0.52)\end{array}$ \\
\hline Surprise & $\begin{array}{c}0.004 \\
(0.76)\end{array}$ & $\begin{array}{c}0.004 \\
(0.75)\end{array}$ & $\begin{array}{c}0.004 \\
(0.93)\end{array}$ & $\begin{array}{c}0.004 \\
(0.93)\end{array}$ \\
\hline$\triangle R O A$ & $\begin{array}{c}-0.007 \\
(-0.20)\end{array}$ & $\begin{array}{c}-0.009 \\
(-0.23)\end{array}$ & $\begin{array}{c}-0.004 \\
(-0.09)\end{array}$ & $\begin{array}{c}-0.005 \\
(-0.14)\end{array}$ \\
\hline Loss & $\begin{array}{c}0.000 \\
(0.03) \\
\end{array}$ & $\begin{array}{c}0.000 \\
(0.01) \\
\end{array}$ & $\begin{array}{c}-0.000 \\
(-0.02) \\
\end{array}$ & $\begin{array}{c}-0.000 \\
(-0.04) \\
\end{array}$ \\
\hline $\mathrm{N}$ & 260,589 & 260,589 & 260,589 & 260,589 \\
\hline $\mathrm{R}^{2}$ & 0.044 & 0.045 & 0.046 & 0.046 \\
\hline Firm FE & YES & YES & YES & YES \\
\hline Year FE & YES & YES & YES & YES \\
\hline Quarter FE & YES & YES & YES & YES \\
\hline Cluster & ANALYST & ANALYST & ANALYST & ANALYST \\
\hline
\end{tabular}

Notes: Table 5 displays analyst characteristics that determine relative information sharing, estimated with OLS regressions, clustered at the analyst level. Column 1-3 display the association with relative information endowment, firm-specific experience, and lagged participation. Column 4 displays the result for all determinants together, thereby providing evidence that relative information advantages are a multidimensional construct represented by relative forecast accuracy, firm-specific experience, and lagged participation. AbnInfo $\boldsymbol{Q}$ captures analysts' information sharing in the question. $\boldsymbol{A b n \boldsymbol { F A }} \boldsymbol{t}$ captures an analysts' relative information endowment measured as analysts' relative forecast accuracy before the conference call in quarter $t$, regarding earnings in quarter $t+1$. AbnFirmExp measures analysts' relative firm experience. LagPartic is an indicator variable equal to 1 if the analyst participated in the conference call in $t-1$. For a detailed overview on the variables please see Appendix 1 . The models are estimated with controls for analysts' characteristics and the firm's information environment, firm, year and quarter fixed effects. $*, * *, * * *$ indicate two-tailed significance at the 10 percent, 5 percent, and 1 percent levels. $t$-values are reported in parentheses. 
Table 6: Mechanism analysis - Determinants of information sharing

\begin{tabular}{|c|c|c|c|c|}
\hline Variables & $\begin{array}{c}(1) \\
\text { AvgInfoQ }\end{array}$ & $\begin{array}{c}(2) \\
A v g I n f o Q\end{array}$ & $\begin{array}{c}(3) \\
\text { AvgInfo } Q\end{array}$ & $\begin{array}{c}(4) \\
\text { AvgInfo } Q\end{array}$ \\
\hline Competition & $\begin{array}{c}-0.002 * * * * \\
(-4.92)\end{array}$ & & & $\begin{array}{c}-0.002 * * * \\
(-4.85)\end{array}$ \\
\hline Uncertaintyt $_{t}$ & & $\begin{array}{c}0.012 * * * \\
(6.50)\end{array}$ & & $\begin{array}{c}0.012 * * * \\
(6.09)\end{array}$ \\
\hline ToneMP & & & $\begin{array}{c}-0.126 * * * \\
(-4.95)\end{array}$ & $\begin{array}{c}-0.112 * * * \\
(-4.40)\end{array}$ \\
\hline Participants & $\begin{array}{c}0.019 * * * \\
(28.99)\end{array}$ & $\begin{array}{c}0.019 * * * \\
(29.58)\end{array}$ & $\begin{array}{c}0.019 * * * \\
(29.60)\end{array}$ & $\begin{array}{c}0.019 * * * \\
(29.03)\end{array}$ \\
\hline Size & $\begin{array}{c}0.001 \\
(1.12)\end{array}$ & $\begin{array}{c}0.000 \\
(0.53)\end{array}$ & $\begin{array}{c}0.001 \\
(0.95)\end{array}$ & $\begin{array}{c}0.000 \\
(0.46)\end{array}$ \\
\hline BTM & $\begin{array}{c}-0.001 \\
(-0.88)\end{array}$ & $\begin{array}{c}-0.001 \\
(-0.77)\end{array}$ & $\begin{array}{c}-0.001 \\
(-0.91)\end{array}$ & $\begin{array}{c}-0.001 \\
(-0.92)\end{array}$ \\
\hline Leverage & $\begin{array}{c}-0.003 * \\
(-1.93)\end{array}$ & $\begin{array}{c}-0.003 * * \\
(-2.21)\end{array}$ & $\begin{array}{c}-0.003^{*} \\
(-1.89)\end{array}$ & $\begin{array}{c}-0.003 * * \\
(-2.19)\end{array}$ \\
\hline Coverage & $\begin{array}{c}-0.001 \\
(-1.60)\end{array}$ & $\begin{array}{c}-0.001 \\
(-1.64)\end{array}$ & $\begin{array}{c}-0.002 * \\
(-1.74)\end{array}$ & $\begin{array}{c}-0.001 \\
(-1.41)\end{array}$ \\
\hline Beat & $\begin{array}{c}0.000 \\
(1.03)\end{array}$ & $\begin{array}{c}0.000 \\
(1.30)\end{array}$ & $\begin{array}{c}0.001 * \\
(1.71)\end{array}$ & $\begin{array}{c}0.001 * \\
(1.85)\end{array}$ \\
\hline Surprise & $\begin{array}{c}0.001 \\
(1.06)\end{array}$ & $\begin{array}{c}0.001 \\
(1.06)\end{array}$ & $\begin{array}{c}0.001 \\
(1.22)\end{array}$ & $\begin{array}{c}0.001 \\
(1.33)\end{array}$ \\
\hline$\triangle R O A$ & $\begin{array}{c}-0.005 \\
(-0.61)\end{array}$ & $\begin{array}{c}-0.003 \\
(-0.47)\end{array}$ & $\begin{array}{c}-0.003 \\
(-0.46)\end{array}$ & $\begin{array}{c}-0.002 \\
(-0.27)\end{array}$ \\
\hline Loss & $\begin{array}{c}0.002^{* * * *} \\
(3.47)\end{array}$ & $\begin{array}{c}0.002 * * * \\
(3.18)\end{array}$ & $\begin{array}{c}0.001 * * * \\
(3.05)\end{array}$ & $\begin{array}{c}0.001 * * * \\
(2.80)\end{array}$ \\
\hline $\mathrm{N}$ & 70,089 & 70,089 & 70,089 & 70,089 \\
\hline $\mathrm{R}^{2}$ & 0.411 & 0.412 & 0.411 & 0.412 \\
\hline Firm FE & YES & YES & YES & YES \\
\hline Year FE & YES & YES & YES & YES \\
\hline Quarter FE & YES & YES & YES & YES \\
\hline Cluster & FIRM & FIRM & FIRM & FIRM \\
\hline
\end{tabular}

Notes: Table 6 displays environment specific determinants of information sharing, estimated with OLS regressions clustered at the firm level. Column 1-3 display the association between competition, uncertainty before the conference call and the tone of the management presentation and information sharing in the conference call. Column 4 provides evidence on the determinants all together. $\boldsymbol{A v g I n f o} \boldsymbol{Q}$ measures the average level of information shared during the conference call of firm $i$. Competition measures the share of participants that has participated in the last quarter as well. Uncertainty $y_{t}$ measures the standard deviation in earnings per share forecasts before the conference call. ToneMP measures the level of tone in the management presentation. We control for the number of participants in the call (Participants) and the firm's information environment (Size, BTM, Leverage, Coverage, Beat, Surprise, $\triangle R$ ROA, and Loss) For a detailed overview on all variables please see Appendix 1. The models are estimated with firm, year and quarter fixed effects. *,**,*** indicate two-tailed significance at the 10 percent, 5 percent, and 1 percent levels. t-values are reported in parentheses. 
Table 7 Panel A: Managements' response to information sharing in analysts' questions

\begin{tabular}{|c|c|c|c|}
\hline Variables & $\begin{array}{c}\text { (1) } \\
\text { AbnInfoA }\end{array}$ & $\begin{array}{c}\text { (2) } \\
\text { AbnInfoA }\end{array}$ & $\begin{array}{c}\text { (3) } \\
\text { AbnInfoA }\end{array}$ \\
\hline$A b n I n f o Q$ & $\begin{array}{c}0.352 * * * \\
(147.88)\end{array}$ & $\begin{array}{c}0.352 * * * \\
(148.23)\end{array}$ & $\begin{array}{c}0.342 * * * \\
(144.35)\end{array}$ \\
\hline AbnTone $Q$ & & $\begin{array}{c}-0.008 * * * \\
(-4.44)\end{array}$ & \\
\hline AbnInfo $Q \times$ AbnTone $Q$ & & $\begin{array}{c}-0.023^{* * *} * \\
(-4.11)\end{array}$ & \\
\hline Abn\#Numbers & & & $\begin{array}{c}-0.047 * * * \\
(-22.72)\end{array}$ \\
\hline AbnInfo $Q \times A b n \#$ Numbers & & & $\begin{array}{c}-0.043 * * * \\
(-7.88)\end{array}$ \\
\hline$A b n F A_{t}$ & $\begin{array}{c}-0.003 \\
(-1.44)\end{array}$ & $\begin{array}{c}-0.003 \\
(-1.43)\end{array}$ & $\begin{array}{c}-0.002 \\
(-1.32)\end{array}$ \\
\hline$A b n \operatorname{Rec}$ & $\begin{array}{c}-0.001 \\
(-0.66)\end{array}$ & $\begin{array}{c}-0.001 \\
(-0.63)\end{array}$ & $\begin{array}{c}-0.002 \\
(-0.87)\end{array}$ \\
\hline Abn\#Forc & $\begin{array}{c}-0.021 * * * \\
(-4.88)\end{array}$ & $\begin{array}{c}-0.021 * * * \\
(-4.91)\end{array}$ & $\begin{array}{c}-0.021 * * * \\
(-4.83)\end{array}$ \\
\hline Abn\#Cотр & $\begin{array}{c}0.002 \\
(0.37)\end{array}$ & $\begin{array}{c}0.002 \\
(0.37)\end{array}$ & $\begin{array}{c}0.001 \\
(0.31)\end{array}$ \\
\hline Abn\#Ind & $\begin{array}{c}0.001 \\
(0.39)\end{array}$ & $\begin{array}{c}0.001 \\
(0.41)\end{array}$ & $\begin{array}{c}0.001 \\
(0.23)\end{array}$ \\
\hline AbnFirmExp & $\begin{array}{c}0.008 * * * \\
(3.16)\end{array}$ & $\begin{array}{c}0.008 * * * \\
(3.14)\end{array}$ & $\begin{array}{c}0.009 * * * \\
(3.54)\end{array}$ \\
\hline AbnGenExp & $\begin{array}{c}-0.004 \\
(-1.14)\end{array}$ & $\begin{array}{c}-0.004 \\
(-1.17)\end{array}$ & $\begin{array}{c}-0.004 \\
(-1.01)\end{array}$ \\
\hline AbnRecHoriz & $\begin{array}{c}-0.015^{* * *} * \\
(-4.63)\end{array}$ & $\begin{array}{c}-0.015^{* * *} * \\
(-4.64)\end{array}$ & $\begin{array}{c}-0.015 * * * \\
(-4.59)\end{array}$ \\
\hline AbnSizeBrok & $\begin{array}{l}-0.003 \\
(-1.28)\end{array}$ & $\begin{array}{l}-0.003 \\
(-1.28)\end{array}$ & $\begin{array}{c}-0.003 \\
(-1.36)\end{array}$ \\
\hline LagPartic & $\begin{array}{c}-0.013 * * * \\
(-9.49)\end{array}$ & $\begin{array}{c}-0.013 * * * \\
(-9.48)\end{array}$ & $\begin{array}{c}-0.012 * * * * \\
(-9.03)\end{array}$ \\
\hline PosQuestion & $\begin{array}{c}0.089 * * * \\
(71.47)\end{array}$ & $\begin{array}{c}0.089 * * * \\
(71.50)\end{array}$ & $\begin{array}{c}0.089 * * * \\
(71.53)\end{array}$ \\
\hline Participants & $\begin{array}{c}-0.072 * * * \\
(-24.27)\end{array}$ & $\begin{array}{c}-0.072 * * * \\
(-24.23)\end{array}$ & $\begin{array}{c}-0.075 * * * * \\
(-25.31)\end{array}$ \\
\hline Size & $\begin{array}{c}-0.002 \\
(-0.67)\end{array}$ & $\begin{array}{c}-0.001 \\
(-0.65)\end{array}$ & $\begin{array}{c}-0.001 \\
(-0.61)\end{array}$ \\
\hline BTM & $\begin{array}{c}-0.004 \\
(-1.21)\end{array}$ & $\begin{array}{c}-0.004 \\
(-1.19)\end{array}$ & $\begin{array}{c}-0.003 \\
(-1.07)\end{array}$ \\
\hline Leverage & $\begin{array}{l}-0.006 \\
(-1.19)\end{array}$ & $\begin{array}{l}-0.006 \\
(-1.16)\end{array}$ & $\begin{array}{l}-0.005 \\
(-1.04)\end{array}$ \\
\hline Coverage & $\begin{array}{c}0.005 \\
(1.46)\end{array}$ & $\begin{array}{c}0.005 \\
(1.44)\end{array}$ & $\begin{array}{c}0.005 \\
(1.41)\end{array}$ \\
\hline Beat & $\begin{array}{l}-0.003 \\
(-1.63)\end{array}$ & $\begin{array}{c}-0.003 * \\
(-1.68)\end{array}$ & $\begin{array}{c}-0.003 * \\
(-1.70)\end{array}$ \\
\hline Surprise & $\begin{array}{c}0.000 \\
(0.00)\end{array}$ & $\begin{array}{c}-0.000 \\
(-0.02)\end{array}$ & $\begin{array}{c}0.000 \\
(0.07)\end{array}$ \\
\hline$\triangle R O A$ & $\begin{array}{c}0.046 \\
(1.43)\end{array}$ & $\begin{array}{c}0.045 \\
(1.40)\end{array}$ & $\begin{array}{c}0.048 \\
(1.47)\end{array}$ \\
\hline Loss & $\begin{array}{c}-0.002 \\
(-0.78) \\
\end{array}$ & $\begin{array}{c}-0.002 \\
(-0.77) \\
\end{array}$ & $\begin{array}{c}-0.001 \\
(-0.69) \\
\end{array}$ \\
\hline $\mathrm{N}$ & 260,589 & 260,589 & 260,589 \\
\hline $\mathrm{R}^{2}$ & 0.198 & 0.198 & 0.201 \\
\hline Firm FE & YES & YES & YES \\
\hline Year FE & YES & YES & YES \\
\hline Quarter FE & YES & YES & YES \\
\hline Cluster & ANALYST & ANALYST & ANALYST \\
\hline
\end{tabular}


Table 7 Panel B: Managements' response to information sharing in analysts' questions

\begin{tabular}{|c|c|c|}
\hline Variables & $\begin{array}{c}\text { (1) } \\
\text { Abn\#WordsA }\end{array}$ & $\begin{array}{c}\text { (2) } \\
\text { Abn\#Answers }\end{array}$ \\
\hline$\overline{A b n I n f o Q}$ & $\begin{array}{c}-0.009 * * * \\
(-3.54)\end{array}$ & $\begin{array}{c}-0.079 * * * \\
(-27.64)\end{array}$ \\
\hline Abn\#Words $Q$ & $\begin{array}{c}0.467 * * * \\
(137.55)\end{array}$ & $\begin{array}{c}0.444 * * * \\
(102.69)\end{array}$ \\
\hline$A b n F A_{t}$ & $\begin{array}{c}-0.001 \\
(-0.76)\end{array}$ & $\begin{array}{c}0.001 \\
(0.46)\end{array}$ \\
\hline AbnRec & $\begin{array}{c}0.014 * * * \\
(6.45)\end{array}$ & $\begin{array}{c}0.005^{*} \\
(1.75)\end{array}$ \\
\hline Abn\#Forc & $\begin{array}{c}0.003 \\
(0.51)\end{array}$ & $\begin{array}{c}0.003 \\
(0.39)\end{array}$ \\
\hline Abn\#Cотр & $\begin{array}{c}0.002 \\
(0.34)\end{array}$ & $\begin{array}{c}-0.017 * * \\
(-2.43)\end{array}$ \\
\hline Abn\#Ind & $\begin{array}{c}0.004 \\
(1.19)\end{array}$ & $\begin{array}{c}-0.001 \\
(-0.13)\end{array}$ \\
\hline AbnFirmExp & $\begin{array}{c}0.003 \\
(1.02)\end{array}$ & $\begin{array}{c}0.027 * * * \\
(7.79)\end{array}$ \\
\hline AbnGenExp & $\begin{array}{c}0.012 * * * \\
(2.68)\end{array}$ & $\begin{array}{c}0.028 * * * \\
(4.93)\end{array}$ \\
\hline AbnRecHoriz & $\begin{array}{c}0.015 * * * \\
(3.58)\end{array}$ & $\begin{array}{c}-0.010 * \\
(-1.94)\end{array}$ \\
\hline AbnSizeBrok & $\begin{array}{c}0.000 \\
(0.17)\end{array}$ & $\begin{array}{l}-0.004 \\
(-1.31)\end{array}$ \\
\hline LagPartic & $\begin{array}{c}0.011 * * * \\
(8.58)\end{array}$ & $\begin{array}{c}0.009 * * * \\
(6.10)\end{array}$ \\
\hline PosQuestion & $\begin{array}{c}-0.046 * * * \\
(-34.90)\end{array}$ & $\begin{array}{c}0.011 * * * \\
(8.27)\end{array}$ \\
\hline Participants & $\begin{array}{c}0.011 * * * \\
(3.56)\end{array}$ & $\begin{array}{c}-0.057 * * * \\
(-17.89)\end{array}$ \\
\hline Size & $\begin{array}{l}-0.002 \\
(-0.75)\end{array}$ & $\begin{array}{c}-0.001 \\
(-0.56)\end{array}$ \\
\hline BTM & $\begin{array}{l}0.006^{*} \\
(1.96)\end{array}$ & $\begin{array}{c}0.005 \\
(1.48)\end{array}$ \\
\hline Leverage & $\begin{array}{c}0.004 \\
(0.86)\end{array}$ & $\begin{array}{c}0.007 \\
(1.30)\end{array}$ \\
\hline Coverage & $\begin{array}{l}-0.006 \\
(-1.50)\end{array}$ & $\begin{array}{c}-0.004 \\
(-0.91)\end{array}$ \\
\hline Beat & $\begin{array}{c}0.003 * * \\
(2.12)\end{array}$ & $\begin{array}{c}0.003 \\
(1.55)\end{array}$ \\
\hline Surprise & $\begin{array}{c}-0.008 * \\
(-1.86)\end{array}$ & $\begin{array}{l}-0.002 \\
(-0.47)\end{array}$ \\
\hline$\triangle R O A$ & $\begin{array}{c}0.013 \\
(0.41)\end{array}$ & $\begin{array}{c}-0.019 \\
(-0.57)\end{array}$ \\
\hline Loss & $\begin{array}{l}-0.002 \\
(-0.75) \\
\end{array}$ & $\begin{array}{c}-0.000 \\
(-0.22) \\
\end{array}$ \\
\hline$\overline{\mathrm{N}}$ & 260,589 & 260,589 \\
\hline $\mathrm{R}^{2}$ & 0.198 & 0.198 \\
\hline Firm FE & YES & YES \\
\hline Year FE & YES & YES \\
\hline Quarter FE & YES & YES \\
\hline Cluster & ANALYST & ANALYST \\
\hline
\end{tabular}


Table 7: Managements' response to information sharing in analysts' questions (continued) Notes: Table 7 displays the relation between information sharing by analysts and manager's response, estimated with OLS regressions, clustered at the analyst level. Panel A displays the association between information sharing by analysts $(\boldsymbol{A b n I n f o} Q)$, the interaction of information sharing and tone, and the interaction of the use of numbers in the question (Abn\#Numbers) and information sharing (AbnInfoQ) with manager's information sharing in the answer. Panel $B$ displays the association between analyst's information sharing on the length of manager's answer (Abn\#WordsA) and the number of answer's by different managers (Abn\#Answers). AbnInfoA measures manager's information sharing in the answer. Abn\#WordsA measures the length of manager's answer. Abn\#Answers measures the number of answers an analyst receives from different managers (e.g., CEO and CFO). AbnInfo $\boldsymbol{Q}$ measures analyst's information sharing in the question. AbnTone $Q$ measures the tone of analyst's question. Abn\#Numbers measures the relative percentage of numbers in the question. For a detailed overview on all variables please see Appendix 1. The models are estimated with controls for analysts' characteristics and the firm's information environment, firm, year and quarter fixed effects. *, **, *** indicate two-tailed significance at the 10 percent, 5 percent, and 1 percent levels. $t$-values are reported in parentheses. 
Table 8: Change in absolute forecast accuracy

\begin{tabular}{|c|c|c|}
\hline & (1) & (2) \\
\hline Variables & $\triangle F A$ & Uncertainty $_{t+1}$ \\
\hline AbnInfo $Q$ & -0.001 & 0.001 \\
\hline AbnInfoA & $\begin{array}{c}-0.000 \\
(-0.56)\end{array}$ & $\begin{array}{c}-0.001 \\
(-1.30)\end{array}$ \\
\hline$A b n F A_{t}$ & $\begin{array}{c}-0.116 * * * \\
(-68.70)\end{array}$ & $\begin{array}{c}-0.004 * * * \\
(-8.90)\end{array}$ \\
\hline$A b n I n f o Q \times A b n I n f o A$ & $\begin{array}{c}0.002 \\
(0.86)\end{array}$ & $\begin{array}{c}-0.001 \\
(-0.61)\end{array}$ \\
\hline$A b n I n f o Q \times A b n F A_{t}$ & $\begin{array}{c}-0.005 * \\
(-1.81)\end{array}$ & $\begin{array}{c}-0.000 \\
(-0.42)\end{array}$ \\
\hline$A b n I n f o Q \times A b n F A_{t}$ & $\begin{array}{c}-0.001 \\
(-0.40)\end{array}$ & $\begin{array}{c}-0.000 \\
(-0.17)\end{array}$ \\
\hline$A b n I n f o Q \times A b n I n f o A \times A b n F A_{t}$ & $\begin{array}{c}0.016 * * \\
(2.53)\end{array}$ & $\begin{array}{c}-0.006 * * \\
(-2.03)\end{array}$ \\
\hline Uncertainty $_{t}$ & & $\begin{array}{c}0.504 * * * \\
(78.74)\end{array}$ \\
\hline AbnRec & $\begin{array}{c}-0.001 \\
(-1.18)\end{array}$ & $\begin{array}{c}-0.000 \\
(-1.28)\end{array}$ \\
\hline Abn\#Forc & $\begin{array}{c}-0.005 * * * \\
(-3.53)\end{array}$ & $\begin{array}{c}0.000 \\
(0.21)\end{array}$ \\
\hline Abn\#Comp & $\begin{array}{c}0.004 * * \\
(2.58)\end{array}$ & $\begin{array}{c}-0.001 \\
(-1.63)\end{array}$ \\
\hline Abn\#Ind & $\begin{array}{c}-0.000 \\
(-0.54)\end{array}$ & $\begin{array}{c}0.000 \\
(0.75)\end{array}$ \\
\hline AbnFirmExp & $\begin{array}{c}0.001 \\
(0.82)\end{array}$ & $\begin{array}{c}0.000 \\
(0.85)\end{array}$ \\
\hline AbnGenExp & $\begin{array}{l}0.000 \\
(0.11)\end{array}$ & $\begin{array}{c}0.000 \\
(0.10)\end{array}$ \\
\hline AbnRecHoriz & $\begin{array}{c}-0.003 * * * \\
(-3.60)\end{array}$ & $\begin{array}{l}0.000 \\
(0.43)\end{array}$ \\
\hline AbnSizeBrok & $\begin{array}{c}0.002 * \\
(1.87)\end{array}$ & $\begin{array}{c}0.001 * \\
(1.81)\end{array}$ \\
\hline LagPartic & $\begin{array}{c}0.001 \\
(1.16)\end{array}$ & $\begin{array}{c}-0.000 * \\
(-1.90)\end{array}$ \\
\hline PosQuestion & $\begin{array}{c}-0.000 \\
(-0.67)\end{array}$ & $\begin{array}{c}0.000 \\
(0.07)\end{array}$ \\
\hline Participants & $\begin{array}{c}0.002 \\
(1.35)\end{array}$ & $\begin{array}{c}0.002 * * * \\
(3.29)\end{array}$ \\
\hline Size & $\begin{array}{c}0.020 * * * \\
(17.91)\end{array}$ & $\begin{array}{c}0.013 * * * \\
(20.00)\end{array}$ \\
\hline BTM & $\begin{array}{c}0.002 \\
(0.81)\end{array}$ & $\begin{array}{c}0.002 * * \\
(2.39)\end{array}$ \\
\hline Leverage & $\begin{array}{l}0.016 * * * \\
\quad(7.04)\end{array}$ & $\begin{array}{l}0.011 * * * \\
(8.94)\end{array}$ \\
\hline Coverage & $\begin{array}{c}0.001 \\
(0.61)\end{array}$ & $\begin{array}{c}-0.004 * * * \\
(-4.60)\end{array}$ \\
\hline Beat & $\begin{array}{c}-0.009 * * * \\
(-12.58)\end{array}$ & $\begin{array}{c}-0.001 * * * \\
(-3.50)\end{array}$ \\
\hline Surprise & $\begin{array}{c}-0.008 * * \\
(-1.97)\end{array}$ & $\begin{array}{c}-0.013 * * * \\
(-6.60)\end{array}$ \\
\hline$\triangle R O A$ & $\begin{array}{c}0.022 \\
(1.11)\end{array}$ & $\begin{array}{c}-0.061 * * * \\
(-5.52)\end{array}$ \\
\hline Loss & $\begin{array}{c}0.005 * * * \\
(3.96)\end{array}$ & $\begin{array}{c}0.004 * * * \\
(6.75)\end{array}$ \\
\hline $\mathrm{N}$ & 260,589 & 260,589 \\
\hline $\mathrm{R}^{2}$ & 0.227 & 0.747 \\
\hline Firm FE & YES & YES \\
\hline Year FE & YES & YES \\
\hline Quarter FE & YES & YES \\
\hline Cluster & ANALYST & ANALYST \\
\hline
\end{tabular}


Table 8: Change in absolute forecast accuracy (continued)

Notes: Table 8 displays the relation between information sharing by a superior analyst and information sharing by a manager on analyst's absolute forecast accuracy and firm-level information uncertainty, estimated with OLS regressions clustered at the analyst level. $\Delta \boldsymbol{F} \boldsymbol{A}$ measures analyst's improvement in absolute forecast accuracy around the call.

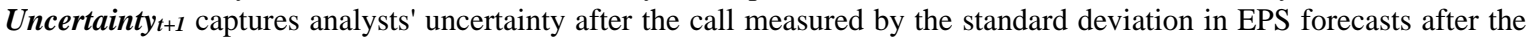
call. AbnInfoA measures manager's information sharing in the answer. AbnFA measures analyst's relative information endowment before the conference call. Uncertainty $t$ measures analysts' standard deviation in EPS forecasts before the call. For a detailed overview on all variables please see Appendix 1. The models are estimated with controls for analysts' characteristics and the firm's information environment, firm, year and quarter fixed effects. *, **, *** indicate two-tailed significance at the 10 percent, 5 percent, and 1 percent levels. t-values are reported in parentheses. 
Table 9: Capital market reaction to information sharing

\begin{tabular}{|c|c|}
\hline Variables & $\begin{array}{c}(1) \\
C A R[0,+1]\end{array}$ \\
\hline AvgInfoQ & $\begin{array}{c}-0.053 * * * \\
(-4.30)\end{array}$ \\
\hline$A v g \operatorname{InfoA}$ & $\begin{array}{c}0.116 * * * \\
(13.31)\end{array}$ \\
\hline$A v g \operatorname{Info} Q \times A v g \operatorname{Info} A$ & $\begin{array}{c}-0.265 * * \\
(-1.97)\end{array}$ \\
\hline AvgToneQ & $\begin{array}{c}2.147 * * * \\
(30.34)\end{array}$ \\
\hline AvgToneA & $\begin{array}{c}0.740 * * * \\
(9.31)\end{array}$ \\
\hline Competition & $\begin{array}{c}0.000 \\
(0.21)\end{array}$ \\
\hline Uncertainty $_{t}$ & $\begin{array}{c}0.024 \\
(0.87)\end{array}$ \\
\hline Participants & $\begin{array}{c}-0.003 * * \\
(-2.54)\end{array}$ \\
\hline Size & $\begin{array}{c}-0.007 * * * \\
(-6.96)\end{array}$ \\
\hline BTM & $\begin{array}{c}0.008 * * * \\
(4.85)\end{array}$ \\
\hline Leverage & $\begin{array}{c}0.003 \\
(1.20)\end{array}$ \\
\hline Coverage & $\begin{array}{c}-0.006 * * * \\
(-3.44)\end{array}$ \\
\hline Beat & $\begin{array}{c}0.029 * * * \\
(32.36)\end{array}$ \\
\hline Surprise & $\begin{array}{c}0.029 * * * \\
(10.43)\end{array}$ \\
\hline$\triangle R O A$ & $\begin{array}{c}0.085 * * * \\
(4.42)\end{array}$ \\
\hline Loss & $\begin{array}{c}-0.004 * * * \\
(-3.61)\end{array}$ \\
\hline $\mathrm{N}$ & 69,900 \\
\hline $\mathrm{R}^{2}$ & 0.152 \\
\hline Firm FE & YES \\
\hline Year FE & YES \\
\hline Quarter FE & YES \\
\hline Cluster & FIRM \\
\hline
\end{tabular}

Notes: Table 9 displays the association between information sharing by analysts and managers and the capital market's reaction, estimated with OLS regressions clustered at the firm-level. $\boldsymbol{C A R}[\mathbf{0},+\mathbf{1}]$ measures the cumulative abnormal sizedecile adjusted return around the conference call. AvgInfo $Q$ measures the average level of information shared by analysts during the conference call of firm $i$. AvgInfoA measures the average level of information shared during the conference call of firm $i$ by managers. For a detailed overview on all variables please see Appendix 1. The model is estimated with controls on the firm's information environement, analysts' incentives (Competition, Uncertainty, and Participants) firm, year and quarter fixed effects. *, **, *** indicate two-tailed significance at the 10 percent, 5 percent, and 1 percent levels. $\mathrm{t}$-values are reported in parentheses. 